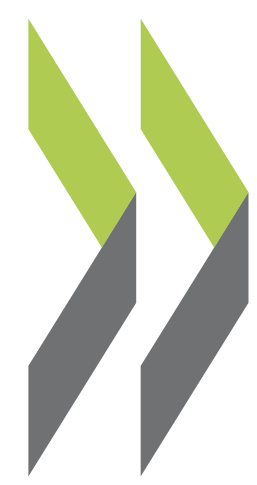

OECD Economics Department Working Papers No. 1636

Automatic fiscal stabilisers: Recent evolution and policy options to boost their effectiveness

\section{Alessandro Maravalle,} kukasz Rawdanowicz 


\section{ECONOMICS DEPARTMENT}

\section{AUTOMATIC FISCAL STABILISERS: RECENT EVOLUTION AND POLICY OPTIONS TO BOOST THEIR EFFECTIVENESS}

\section{ECONOMICS DEPARTMENT WORKING PAPERS No. 1636}

By Alessandro Maravalle and Łukasz Rawdanowicz

OECD Working Papers should not be reported as representing the official views of the OECD or of its member countries. The opinions expressed and arguments employed are those of the author(s).

Authorised for publication by Alain de Serres, Deputy Director, Policy Studies Branch, Economics Department.

All Economics Department Working Papers are available at www.oecd.org/eco/workingpapers.

JT03469618 
OECD Working Papers should not be reported as representing the official views of the OECD or of its member countries. The opinions expressed and arguments employed are those of the author(s).

Working Papers describe preliminary results or research in progress by the author(s) and are published to stimulate discussion on a broad range of issues on which the OECD works.

Comments on Working Papers are welcomed, and may be sent to OECD Economics Department, 2 rue André Pascal, 75775 Paris Cedex 16, France, or by e-mail to eco.contact@oecd.org.

All Economics Department Working Papers are available at www.oecd.org/eco/workingpapers.

This document and any map included herein are without prejudice to the status of or sovereignty over any territory, to the delimitation of international frontiers and boundaries and to the name of any territory, city or area.

The statistical data for Israel are supplied by and under the responsibility of the relevant Israeli authorities. The use of such data by the OECD is without prejudice to the status of the Golan Heights, East Jerusalem and Israeli settlements in the West Bank under the terms of international law.

You can copy, download or print OECD content for your own use, and you can include excerpts from OECD publications, databases and multimedia products in your own documents, presentations, blogs, websites and teaching materials, provided that suitable acknowledgment of OECD as source and copyright owner is given. All requests for commercial use and translation rights should be submitted to PubRights@oecd.org 


\title{
Automatic fiscal stabilisers: Recent evolution and policy options to boost their effectiveness
}

\begin{abstract}
Building on the automatic fiscal stabilisers literature, this paper assesses how automatic stabilisers have evolved over the past two decades by analysing changes in the personal income tax and social benefit systems. In three-quarters of the 35 OECD countries analysed, indicators of the strength of automatic stabilisers (aggregate elasticities of household income after tax with respect to the cycle and aggregate net replacement rates) changed little or moderately over the past two decades, suggesting broadly stable automatic stabilisers of household disposable income. The paper discusses pros and cons of several policy options to strengthen automatic stabilisers in the current environment. The effectiveness and possible side effects, particularly related to disincentives to work, vary across policy options. Consequently, policy reform proposals should be carefully assessed in a country-specific context and take into account other important policy objectives of tax and benefit systems.
\end{abstract}

JEL classification codes: H31, H6, E6, E32.

Keywords: automatic fiscal stabilisers; fiscal policy; business cycles.

\section{Stabilisateurs budgétaires automatiques : Évolution récente et options offertes aux pouvoirs publics pour en augmenter l'efficacité}

\section{Résumé}

À partir de la littérature consacrée aux stabilisateurs budgétaires automatiques, le présent document évalue la manière dont les stabilisateurs automatiques ont évolué au cours des deux dernières décennies, en analysant les changements intervenus dans l'imposition du revenu des personnes physiques et dans les systèmes de prestations sociales. À Dans trois quarts de 35 économies de la OCDE analysés, des indicateurs de l'efficacité de stabilisateurs budgétaires automatiques (les élasticités agrégées du revenu des ménages après impôt et les taux de remplacement nets agrégés) ont varié peu ou de façon modéré au cours des deux dernières décennies, suggérant que les stabilisateurs automatiques du revenu disponible des ménages ont été globalement stables. Cet article expose les avantages et les inconvénients de plusieurs mesures pouvant être prises par les pouvoirs publics pour renforcer les stabilisateurs automatiques dans le contexte actuel. Leur efficacité et leurs effets indésirables éventuels, notamment en termes de désincitation au travail, varient selon les options examinées. En conséquence, les propositions de réforme de l'action publique doivent être soigneusement évaluées dans chaque contexte national, et tenir compte d'autres importants objectifs des pouvoirs publics concernant les systèmes de prélèvements et de prestations.

JEL classification codes: H31, H6, E6, E32.

Mots-clés : stabilisateurs automatiques ; politique budgétaire ; cycles conjoncturels. 


\section{Table of Contents}

\section{Automatic fiscal stabilisers: Recent evolution and policy options to boost their effectiveness}

1.

Introduction

2. Did automatic fiscal stabilisers change in the two decades before the COVID-19 crisis? 6

2.1. Changes in automatic fiscal stabilisers related to direct taxes on households 10

2.2. Changes in automatic fiscal stabilisers related to social benefits 13

3. What can be done to make automatic fiscal stabilisers more effective? 14

3.1. Increasing the timeliness of automatic fiscal stabilisers 15

3.2. Changing the tax system 15

3.3. Improving the unemployment benefit system 21

3.4. Introducing automatic direct payments to individuals during recessions 23

3.5. Automatic fiscal stabilisers for businesses 24

4. Other policy measures to help economic stabilisation 24

4.1. Short-term work compensation schemes 25

4.2. Active labour market policies 26

5. Fiscal space and automatic fiscal stabilisers $\quad 27$

Bibliography $\quad 29$

\section{Figures}

Figure 1. Revisions of the semi-elasticity and its components between 2005 and 2015

Figure 2. Relaxing the assumption of the constant shares of taxes in GDP affects the revenue semi-elasticity Figure 3. Measures of automatic fiscal stabilisers are positively correlated with structural tax and benefit parameters

Figure 4. Automatic fiscal stabilisers related to direct taxes on households changed little

Figure 5. Automatic fiscal stabilisers related to direct taxes on households tended to converge to the crosscountry average

Figure 6. Automatic fiscal stabilisers related to social benefits changed little in the majority of countries

Figure 7. Personal income tax systems differ across OECD countries

8. Relation between tax progressivity and the strength of automatic fiscal stabilisers

Figure 9. Relation between the size of shock and the strength of automatic fiscal stabilisers 18

Figure 10. Relation between income inequality and the tax elasticity $\quad 19$

Figure 11. Personal income taxes are more elastic than social security contributions 20

Figure 12. Social security contributions and indirect taxes are larger than direct taxes on households in many OECD countries

Figure 13. The degree of unemployment protection decreases with its duration 21

Figure 14. Spending on active labour market policies (ALMP) 27

Figure 15. Cumulative negative output gaps over a business cycle can be very large 28

Figure A Error! No text of specified style in document..1. Level and changes in the strength of tax-based automatic stabilisers across household type

\section{Boxes}

Box 1. Cyclical adjustment of budget balances and the semi-elasticity 7

Box 2. Determinants of the elasticity of direct taxes on households with respect to income 17 


\title{
Automatic fiscal stabilisers: Recent evolution and policy options to boost their effectiveness
}

\author{
By Alessandro Maravalle and Łukasz Rawdanowicz ${ }^{1}$
}

\section{Introduction}

1. Automatic fiscal stabilisers refer to changes in government spending and revenues that help stabilise the economy after negative and positive shocks without any discretionary policy intervention. Countries with larger and more effective automatic fiscal stabilisers need less discretionary changes in public spending and revenues to stabilise the economy for a given shock. This feature becomes particularly important when the effectiveness of monetary policy in stabilising cyclical changes in the economy is diminished at the zero lower bound (Eichenbaum, 2019; Blanchard and Summers, 2020). In principle, automatic fiscal stabilisers are temporary and do not affect the structural fiscal policy stance, reducing chances of a pro-cyclical fiscal policy. They are also generally timely as they do not suffer from the information, decision, design and implementation lags. Thus, automatic stabilisers are generally preferred over discretionary fiscal stimulus to react to temporary negative shocks (Blanchard et al., 2010; Sutherland et al., 2010). Automatic stabilisers also help predict changes in government budget balances in response to the economic cycle.

2. In this context, estimates of the size and duration of automatic fiscal stabilisers are important for policymakers to take informed policy decisions to foster economic stability. Several methods of estimating automatic fiscal stabilisers exist (in 't Veld et al., 2012; Mohl et al., 2019; Maravalle and Rawdanowicz, 2020). They differ with regard to the concept of stabilisation and the nature of shocks, and any international comparison should account for these differences.

3. Building on the automatic stabilisation literature, this paper assesses how automatic fiscal stabilisers have changed over the past two decades, and discusses pros and cons of several policy options to strengthen them in the current environment. The main findings are:

- With the exception of few countries that undertook important tax reforms, the aggregate elasticity of income after tax, a measure of the sensitivity of household net income to changes in gross

1 The authors are economists at the OECD Economics Department. Corresponding author: lukasz.rawdanowicz@oecd.org. The authors would like to thank Sveinbjörn Blöndal, Jarmila Botev, Aida Caldera Sanchez, Oliver Denk, Alberto Gonzalez Pandiella, Philip Hemmings, Alexander Hijzen, Elena Rusticelli, Stephane Sorbe, Enes Sunel and David Turner for useful comments and suggestions; Sylvie Foucher-Hantala and Ane Kathrine Christensen for excellent statistical assistance; and Isabelle Fakih for final preparation of the document. 
wages and thus of the strength of related automatic stabilisers, has changed little over the past two decades. Similarly, in around two-thirds of the OECD countries, the aggregate net replacement rate - the fraction of net income that is maintained when becoming unemployed and a proxy of automatic stabilisation via social benefits - did not change much between 2001 and 2018, and, in more than half of the OECD countries, it declined slightly.

- While affecting automatic fiscal stabilisers usually is not the main and direct motivation for reforms of tax and benefit systems, some measures could help to strengthen automatic stabilisers and also to reduce inequality. The main policy options to boost automatic stabilisers include making personal income taxation more progressive, changing the structure of taxes towards highly elastic taxes that affect household disposable income directly, and making unemployment benefits more generous and introducing direct payments to households during severe recessions. Beyond purely automatic fiscal stabilisers, short-term work compensation schemes and well-designed active labour market policies could help stabilise the economy in case of negative shocks.

- The effectiveness and possible side effects, particularly related to disincentives to work stemming from higher taxes and generous unemployment benefits, differ across these policy options. Besides, it may be difficult to calibrate policy changes to achieve a given degree of automatic stabilisation. Thus, policy reform proposals should be carefully assessed in a country-specific context and take into account other important policy objectives of tax and benefit systems, including ensuring sufficient tax revenues, stimulation of growth and employment, and a more equitable income redistribution.

- Full and smooth operation of automatic fiscal stabilisers will crucially depend on sufficient fiscal space as fears about debt sustainability or authorities' preference for lower debt may lead governments to offset automatic stabilisers with discretionary fiscal tightening. There is some tentative evidence about such behaviour in the past. As large automatic stabilisers may have persistent budgetary effects when negative output gaps prevail, they may limit government's control over the overall budget balance, raising the possibility of implementing discretionary offsets.

\section{Did automatic fiscal stabilisers change in the two decades before the COVID-19 crisis?}

4. A few approaches have been used to quantify automatic fiscal stabilisers, each with their pros and cons (in 't Veld et al., 2012; Mohl et al., 2019; Maravalle and Rawdanowicz, 2020). They use different definitions of stabilisation and refer to different types of shocks which makes them difficult to compare. ${ }^{2}$ Micro simulations replicate an income tax system and use household-level data to assess the direct stabilisation role of automatic fiscal stabilisers in smoothing household disposable income typically after a shock to market income (Auerbach and Feenberg, 2000; Mohl et al., 2019). This approach allows researchers to use tax and benefit system details to better predict individual reactions. However, it may be less accurate in predicting macroeconomic outcomes, partly due to not accounting for endogenous feedbacks. The automatic stabilisation of aggregate household disposable income after a shock to market income can also be investigated at a macro level (Maravalle and Rawdanowicz, 2020). ${ }^{3}$ This alternative

\footnotetext{
${ }^{2}$ Indeed, different approaches can produce different ranking of countries by the strength of automatic fiscal stabilisers (Mohl et al., 2019).

${ }^{3}$ Automatic stabilisers absorb on average around $60 \%$ of the specific shock to market income from lower employment and wage rates (in absolute terms) in the first year, ranging from around $80 \%$ in Germany and the Netherlands to below $40 \%$ in Spain, the Slovak Republic, Japan and Greece (Maravalle and Rawdanowicz, 2020).
} 
approach is based on the national account identity of household disposable income and elements of the OECD cyclical-adjustment framework (Box 1). In contrast to micro approaches, macro simulations aim to capture both direct and indirect effects of automatic fiscal stabilisers, by allowing an endogenous response of households and fiscal and monetary policies to the shock, and help measure stabilisation of household consumption (van den Noord, 2000; in 't Veld et al., 2013; Mckay and Reis, 2016).

5. The size of automatic fiscal stabilisers could also be inferred implicitly from the framework of adjusting budget balances for cyclical changes (Girouard and André, 2005; Price et al., 2015). In this framework, the semi-elasticity indicates by how much the budget-balance-to-GDP ratio changes for a given change in the output gap in the absence of discretionary fiscal measures (Box 1). ${ }^{4}$ The semi-elasticity is larger in countries where the share in GDP of budget components more sensitive to changes in the cycle is larger. These countries should have strong automatic fiscal stabilisers in principle.

6. Assessing changes in automatic fiscal stabilisers based on the above approaches is difficult as they use constant (estimated or calibrated) elasticities, unless they are available for different points in time (Box 1). One indirect way to analyse the evolution of automatic stabilisers over time is to measure changes in the parameters of personal income tax (PIT) and social benefit systems. Countries with increasingly more progressive direct taxes on households (Box 2) and more generous and more widely available social benefits have stronger automatic stabilisers. These parameters are available for a large set of countries since $2000 .^{5}$

\section{Box 1. Cyclical adjustment of budget balances and the semi-elasticity}

The so-called semi-elasticity $(\varepsilon)$ is an aggregate metric that can be used to adjust the ratio of budget balance (B) to GDP for the cycle and to estimate a cyclically-adjusted balance (CAB) - Mourre et al. (2013) and Price et al. (2015):

$$
C A B / G D P-B / G D P \cong-\varepsilon * G A P, \quad \varepsilon=\left[\frac{R}{G D P} \sum_{i} \frac{R_{i}}{R}\left(\eta_{i}-1\right)-\frac{E}{G D P} \sum_{j} \frac{\mathrm{E}_{j}}{\mathrm{E}}\left(\eta_{j}-1\right)\right]
$$

where $R$ is total government revenues, $E$ is total government expenditures, $\eta$ is a constant elasticity of the level of $i$-th revenue or $j$-th expenditure category with respect to the output gap (GAP), and each component of the cyclically-adjusted budget, $X^{*}$, is calculated as:

$$
X^{*}=X\left(\frac{Y^{*}}{Y}\right)^{\eta}=X(1+G A P)^{-\eta}
$$

For each budget item, $\eta$ is a product of two elasticities: the elasticity of tax revenue/expenditure with respect to tax/expenditure base $\left(\eta_{b}\right)$; and the elasticity of the tax/expenditure base with respect to the output gap $\left(\eta_{b, \text { gap }}\right) . \eta_{b}$ captures the sensitivity of tax revenues/expenditure to a change in tax/expenditure base, a higher value pointing to a stronger capacity of stabilisation of automatic fiscal stabilisers, while $\eta_{b, g a p}$ measures the sensitivity of the tax/expenditure base to the cycle.

\footnotetext{
4 The OECD average of the estimated semi-elasticities is 0.5 , ranging from below 0.4 in Korea, Latvia and the Slovak Republic to around 0.66 in in Belgium, Sweden and Denmark (Price et al., 2015).

${ }^{5}$ Assessing the evolution of the tax progressivity over a longer period is difficult due to lack of data. In the United States, the tax reforms in the 1980s - that lowered marginal tax rates significantly, in particular the top one, reduced the number of tax brackets from 16 to four, and broadened the tax base - are estimated to have halved consumption stabilisation (Kniesner and Ziliak, 2002). Prior to these reforms, the progressive income tax system stabilised household consumption by $15 \%$ in response to a given decline in gross income.
} 


\section{Changes in the semi-elasticity over time}

Price et al. (2015) updated OECD semi-elasticity estimates from 2005 (Girouard and André, 2005). Their work provides some indication about changes in automatic fiscal stabilisers in the OECD economies, even if only two vintages of semi-elasticities can be compared. In most countries, the semi-elasticity increased between 2005 and 2015 (Figure 1, Panel A). ${ }^{1}$ This reflects a combination of factors related to revisions of estimated elasticities, changes in the methodology and an evolving structure and size of budget balances. As the importance of these factors varies across the countries, it is difficult to identify a dominating factor. Focusing on selected elasticity can however provide some insights.

\section{Figure 1. Revisions of the semi-elasticity and its components between 2005 and 2015}

A. Total semi-elasticity

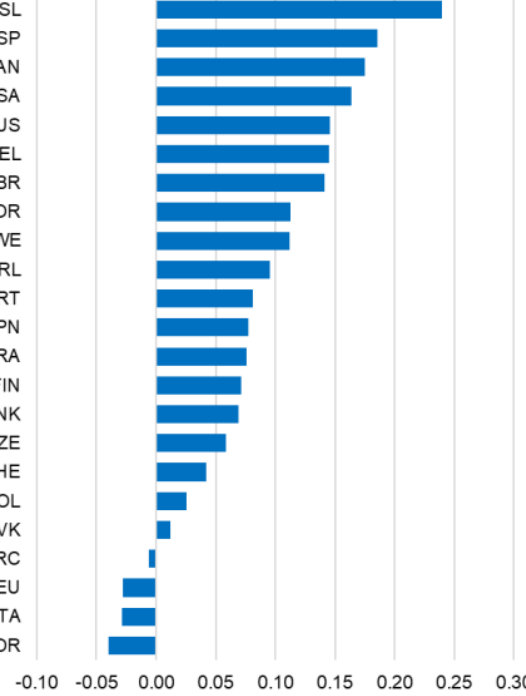

B. Elasticity of personal income taxation with respect to the output gap

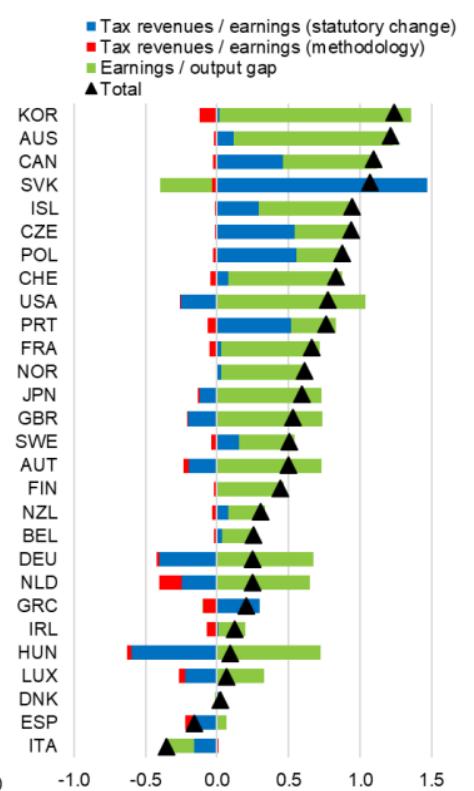

C. Elasticity of corporate income taxation with respect to the output gap

- Corporate tax/profits =Profits/output gap $\Delta$ Total

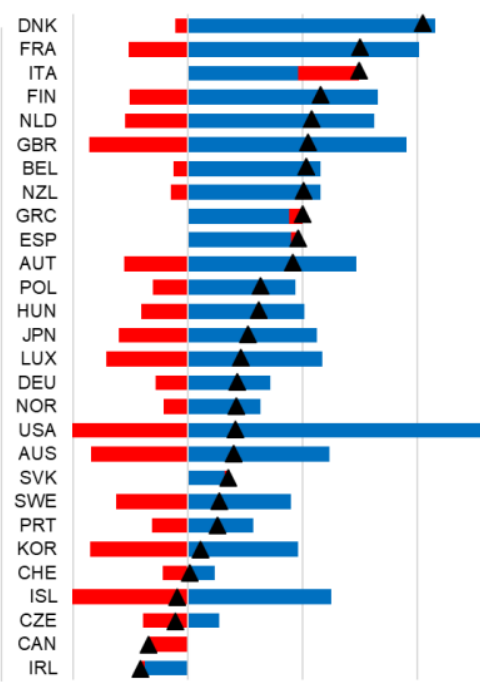
2.0

Note: $2005-15$ revision of the total semi-elasticity (Panel A) and of the elasticity of personal income taxation (PIT) and corporate income taxation (CIT) with respect to the output gap (Panels B and C), as reported in Price et al. (2015), based on 2002-11 average revenue and expenditure shares. The revision of the elasticity of PIT with respect to the output gap is decomposed into the revisions of the elasticity of earnings with respect to the output gap (green bar) and of the earning elasticity of tax revenues. The latter is further decomposed into a component due to the adoption of a new methodology (red bar) and due to changes in statutory taxation (blue bar). The revision of the output gap elasticity of CIT is decomposed into a change in the elasticity of corporate income tax with respect to corporate profits (blue bars) and the change in the elasticity of corporate profits with respect to the output gap (red bars).

Source: Girouard, N. and C. André (2005), "Measuring Cyclically-Adjusted Budget Balances for OECD Countries," OECD Economics Department Working Papers, No. 434; and Price, R., T. Dang and J. Botev (2015), "Adjusting fiscal balances for the business cycle: New tax and expenditure elasticity estimates for OECD countries", OECD Economics Department Working Papers, №. 1275.

\section{Revisions of the elasticities for direct taxes}

While in most OECD countries both the elasticity of personal income taxes (PIT) and the elasticity of corporate income taxes (CIT) with respect to the output gap were revised up between 2005 and 2015, the reasons for these revisions differed. For PIT, the change was primarily due to an upward revision of the elasticity of earnings with respect to the output gap, possibly reflecting changes in the nature of economic cycles and the structure of the economy (Figure 1, Panel B). Revisions to the elasticity of PIT with respect 
to the tax base (earnings), which reflect changes in the tax code, were smaller and more heterogeneous across countries. In eight OECD countries (Canada, the Czech Republic, Greece, Ireland, Poland, Portugal, the Slovak Republic and Sweden), the tax elasticity increased by at least $10 \%$, whereas in five countries (Germany, Hungary, the Netherlands, the United Kingdom and the United States), it weakened by at least $10 \%$. Revisions due to the methodology modifications were marginal. Regarding $\mathrm{CIT}$, the revisions were mainly due to a large upward revision of the elasticity of corporate income taxes with respect to profits in the majority of countries (Figure 1, Panel C). In contrast, corporate profits became less sensitive to the cycle.

\section{The role of the size and composition of budget revenues}

The semi-elasticities reported in Price et al. (2015) are based on the average shares of specific revenues and expenditures in GDP. Thus, the change over time in size and structure of budget balances can affect the semi-elasticity. For instance, the revenue semi-elasticity varied, on average, by around $15 \%$ between 1980 and 2018, with particularly big differences in Finland, the Netherlands and the Slovak Republic, with changing shares of taxes in GDP (Figure 2).

\section{Figure 2. Relaxing the assumption of the constant shares of taxes in GDP affects the revenue semi elasticity}

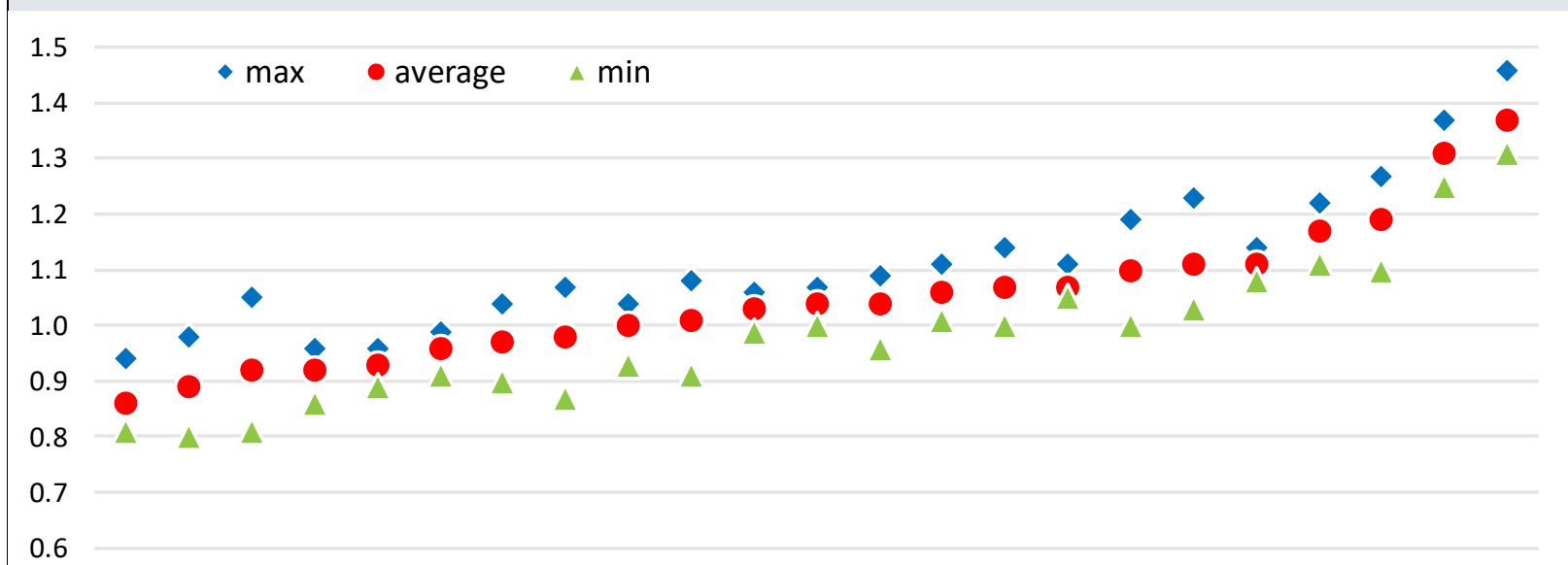

SVN SVK FIN GRC DEU CZE FRA NLD ITA HUN BEL IRL PRT AUT SWE LUX ESP JPN CHE CAN USA GBR AUS

Note: The semi-elasticity for revenues is calculated using the elasticities of four revenue categories (direct taxes on households; direct taxes on businesses; social security contributions; and indirect taxes) with respect to the output gap and their actual shares in GDP. Maximum, average and minimum values refer to the $1980-2018$ period.

Source: Price, R., T. Dang and J. Botev (2015), "Adjusting fiscal balances for the business cycle: New tax and expenditure elasticity estimates for OECD countries", OECD Economics Department Working Papers, No. 1275; OECD Economic Outlook 106 database; and authors' calculations.

1. For discussion of levels of the semi-elasticities and cross-country differences see Price et al. (2015) and Maravalle and Rawdanowicz (2020).

7. The structural parameters of the tax code and benefit systems have a direct impact on some of the elasticities used in the cyclical adjustment of budget balances (Box 1) and for calculating the measure of effectiveness of household disposable income stabilisation (Maravalle and Rawdanowicz, 2020). 
Indeed, the structural indicator of the strength of automatic fiscal stabilisers related to direct taxes on households discussed below is strongly positively correlated (0.7) with the component of effectiveness of automatic fiscal stabilisers due to direct taxes on households and social security contributions (Figure 3, Panel A). Similarly, the aggregate net replacement rate used below as an indicator of the strength of automatic fiscal stabilisers related to social benefits is positively correlated $(0.4)$ with the component of effectiveness of automatic stabilisers related to social benefits (Figure 3, Panel B).

\section{Figure 3. Measures of automatic fiscal stabilisers are positively correlated with structural tax and} benefit parameters

A. Automatic stabilisers related to direct taxes on households ${ }^{1}$

70

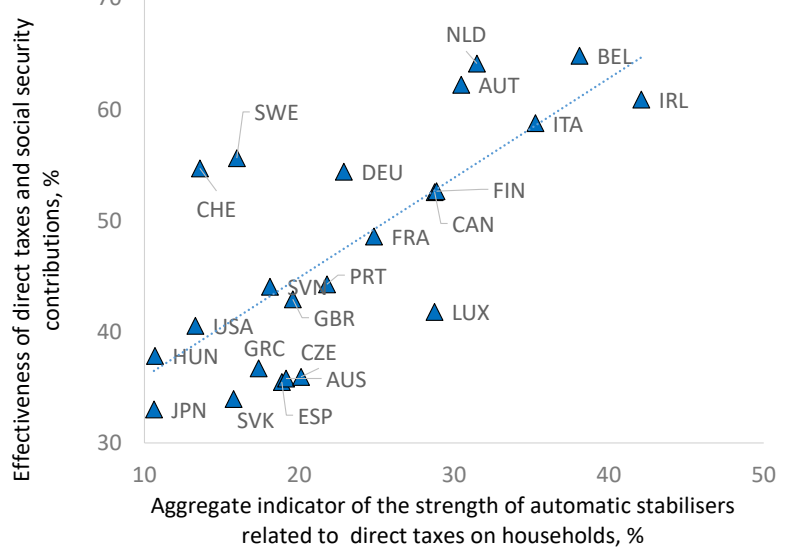

B. Automatic stabilisers related to social benefits ${ }^{2}$

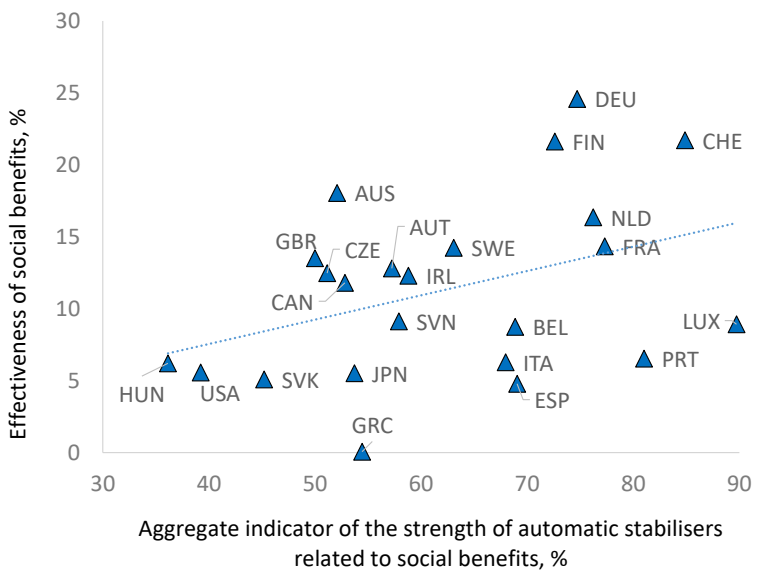

1. The vertical axis shows the component of the effectiveness of automatic fiscal stabilisers due to direct taxes on households and social security contributions as calculated in Maravalle and Rawdanowicz (2020). The horizontal axis shows the aggregate indicator of the strength of automatic stabilisers related to household direct taxation as discussed below. The two indicators are strongly positively correlated (0.7).

2. The vertical axis shows the component of the effectiveness of automatic fiscal stabilisers due to social benefits (unemployment, housing and family) as calculated in Maravalle and Rawdanowicz (2020). The horizontal axis shows the aggregate indicator of the strength of automatic stabilisers related to social benefits approximated by the aggregate net replacement ratio for an average household in case of 12-month unemployment. The two indicators are positively correlated (0.4).

Source: 2019 OECD Taxing Wages database; 2019 OECD Income Distribution database; 2019 OECD Social Protection and Well-being database; Maravalle, A. and $Ł$. Rawdanowicz (2020), "How Effective Are Automatic Fiscal Stabilisers in the OECD Countries", OECD Economics Department Working Papers, No. 1635; and authors' calculations.

\subsection{Changes in automatic fiscal stabilisers related to direct taxes on households}

8. The strength of automatic fiscal stabilisers related to direct taxes on households can be approximated by the elasticity of after-tax household income. This elasticity measures the sensitivity of household net income to changes in gross wages, and takes into account most characteristics of the PIT system, including tax reliefs, tax allowances, tax credits, tax rate structures, employee and employer social security contribution payable on wage earnings and government household cash transfers. ${ }^{6}$ The elasticity of after-tax income is available for most of the OECD countries for eight representative household types that differ in family composition (single vs married couple, with or without children) and income level.

\footnotetext{
${ }^{6}$ It is based on the average gross wage earning of a full-time worker employed during the entire year, and it covers all sectors of the economy. Thus, it does not include unemployment benefits. Also, income tax on capital income, net wealth taxes and all indirect taxes are excluded.
} 
9. The disaggregated data help a more granular analysis of differences in taxation but do not indicate automatic stabilisation for the household sector as a whole. ${ }^{7}$ Thus, an aggregate indicator is built as a weighted average of elasticities of after-tax income for the eight household types. Each representative household type is weighted by its share in total population reported in the OECD Income Distribution database. Due to lack of information on the relative proportion of a household type across income levels, the aggregation neglects differences in income distribution within and across household types. ${ }^{8}$ The weights are kept constant at the 2000-18 average of the shares of household types in total population to focus on policy-related changes in the tax system and to abstract from effects of changes in households' composition. ${ }^{9}$ To facilitate the interpretation of the indicator, the elasticity is transformed linearly so that it usually ranges between 0 (no automatic stabilisation, i.e. the percentage change in net income is equal to the percentage change in gross wages) and 100 (full automatic stabilisation, i.e. net income does not change at all when gross wages change). ${ }^{10}$

10. The aggregate elasticity of income after tax with respect to the cycle and thus the strength of related automatic fiscal stabilisers have changed little or moderately in nearly three-quarters of the OECD countries between 2000 and 2018, i.e. below one standard deviation of the distribution of changes in absolute terms for all countries (Figure 4). Reflecting important tax reforms, the largest increase was in Ireland and New Zealand, and the largest decline was in Hungary. ${ }^{11}$ In general, countries with relatively weaker automatic fiscal stabilisers related to direct taxes on household (i.e. below the cross-country average) at the beginning of the period tended to strengthen them, and vice versa (Figure 5).

\footnotetext{
${ }^{7}$ Disaggregate data at the level of household types provide information on the factors behind the observed change in the stabilisation properties of the tax system in a country as a whole (Figure A.A.1 in Annex A).

8 Implicitly, this amounts to assuming that for any household within a household type the average impact of automatic stabilisers related to direct taxes on households is equivalent to that of a household where the principal earner earns the average income.

9 Taking into account actual changes in the shares does not change the findings substantially.

10 The elasticity of after-tax income for a given household type is defined as $\mathrm{E}=(1-M R) /(1-A R)$, where $M R$ is the marginal tax rate and $A R$ is the average tax rate. The linear transformation is: $100^{*}(1-\mathrm{E})$. This after-tax elasticity is perfectly negatively correlated with the elasticity of tax revenues with respect to gross earnings in Box 2 (e=MR/AR).

${ }^{11}$ In Ireland, income levy was introduced, social security and healthcare levies were increased, and the tax relief on pension contributions was reduced in 2011-12 (OECD, 2011a). New Zealand implemented two tax reforms in 2004-05 and 2009-10, with important changes to PIT, tax credits for families and higher marginal tax rate. Hungary undertook a vast tax reform in 2011-12, including the introduction of a flat-rate taxation of personal income, which reduced the tax progressivity significantly (OECD, 2012).
} 
Figure 4. Automatic fiscal stabilisers related to direct taxes on households changed little Change in the transformed aggregated elasticity of after-tax income between 2000 and 2018, percentage points

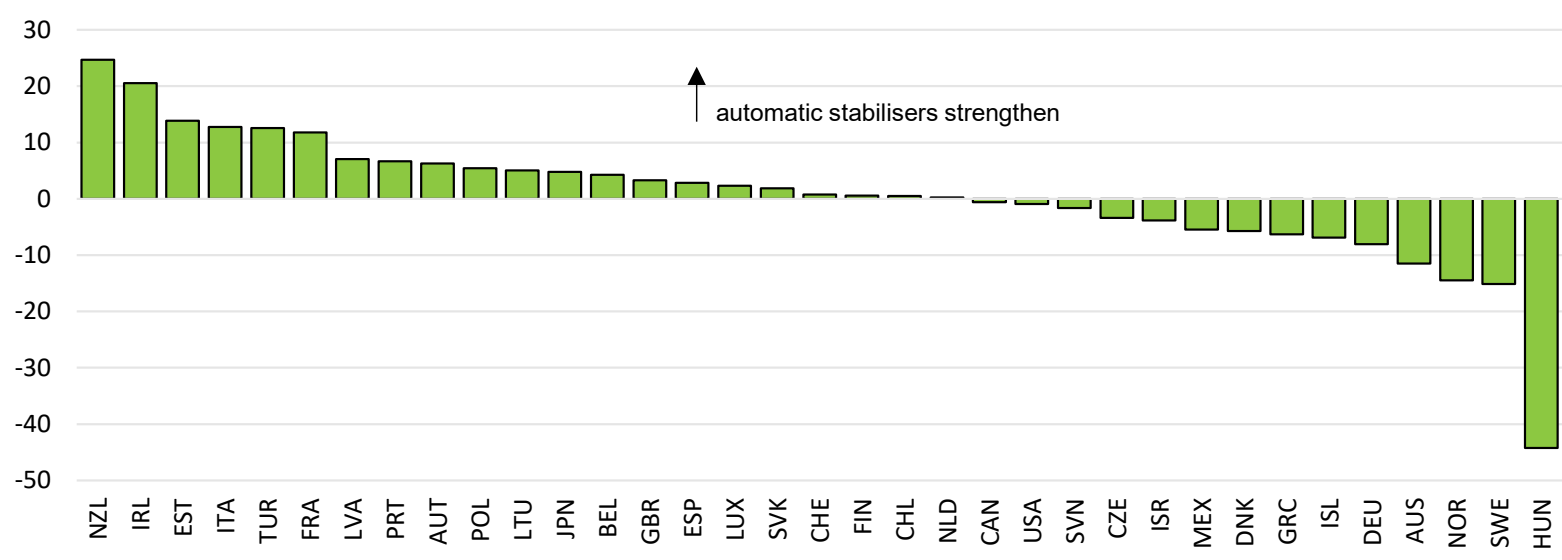

Note: The aggregate elasticity of after-tax income is a weighted average of the elasticities of the eight representative household types in the Taxing Wages database and that differ in family composition (single vs married couple, with or without children) and income level. The weights refer to average shares of a specific household type in total population over 2000-18. The aggregate elasticity is then transformed linearly as $100^{*}(1-E)$, so the transformed elasticity ranges between 0 and 100 , with a higher value pointing to stronger stabilisation of net income.

Source: 2019 OECD Taxing Wages database; 2019 OECD Income Distribution database; and authors' calculations.

Figure 5. Automatic fiscal stabilisers related to direct taxes on households tended to converge to the cross-country average

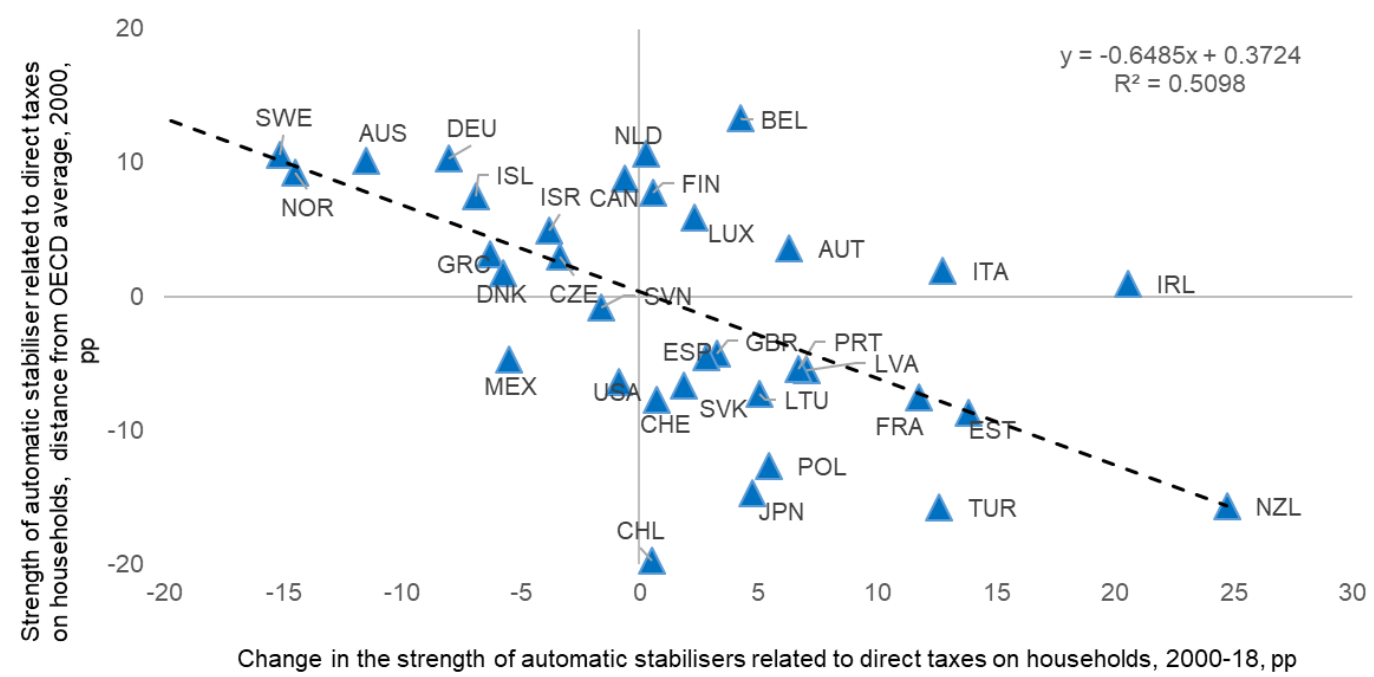

Note: The horizontal axis shows the change in the transformed aggregated elasticity of after-tax income over 2000-18. The vertical axis shows the level of the transformed aggregated elasticity in 2000 as a difference from the cross-country average in 2000 . The two variables are strongly negatively correlated $(-0.7)$. The correlation drops (in absolute terms) to -0.5 when countries with the largest changes (i.e. Hungary, Ireland and New Zealand) are excluded. Hungary is not shown.

Source: 2019 OECD Taxing Wages database; 2019 OECD Income Distribution database; and authors' calculations. 


\subsection{Changes in automatic fiscal stabilisers related to social benefits}

11. The evolution of automatic fiscal stabilisers related to social benefits can be measured by a net replacement rate, which shows the share of average in-work household disposable income that is maintained when one member of the household becomes unemployed. A higher net replacement rate indicates a more generous social benefit system and thus stronger automatic stabilisation. The net replacement rate accounts for social assistance, family, lone-parents, housing, and unemployment benefits. As with the elasticity of after-tax income, net replacement rates are available for eight household types and a weighted average is calculated to have an indicator relevant for the whole economy. ${ }^{12}$ The aggregate net replacement rate is computed for two different unemployment durations - short-term (up to one year) and long-term (up to two years), as unemployment benefits tend to fall with the duration of unemployment.

12. In around two thirds of the OECD countries, the aggregate net replacement rates - both for short-term and longer-term unemployment - changed little between 2001 and 2018, and in more than half of the OECD countries they declined slightly (Figure 6). The net replacement rates declined more significantly only in few countries, including Chile, Germany, Sweden, the United States and few central European countries. In contrast, the net replacement rate increased considerably in Italy, reflecting the introduction of the unified unemployment benefit system (NASPI) in 2015 (OECD, 2017). Unlike for the automatic fiscal stabilisers related to direct taxes on households, there is no clear correlation across the OECD countries between the initial levels of net replacement rates and their changes over the past two decades.

\footnotetext{
12 Based on eight different household types in which the earnings of the principal earner amount to $100 \%$ of the average wage. They differ in family composition ("single", "one-earner couple" and "two-earner couple") and, if relevant, in the level of income of the second earner ( $67 \%$ or $100 \%$ of the average wage). The weights of each household type reflects its share in total population as reported in the OECD distribution income database. The weights are kept constant at the 2001-18 average of the shares of household types in total population to focus on policy-related changes in the social benefit system and to abstract from effects of changes in households' composition. However, this database does not provide information on the income distribution within each household type. Thus, aggregation neglects differences in income distribution within a household type. Results are robust to taking household types where earnings of the principal earner amount to $67 \%$ rather than $100 \%$ of the average wage, and also to using a specific type of households only (single, one-earner and two-earners).
} 
Figure 6. Automatic fiscal stabilisers related to social benefits changed little in the majority of countries

Change in the aggregate net replacement rate (2001-18), percentage points

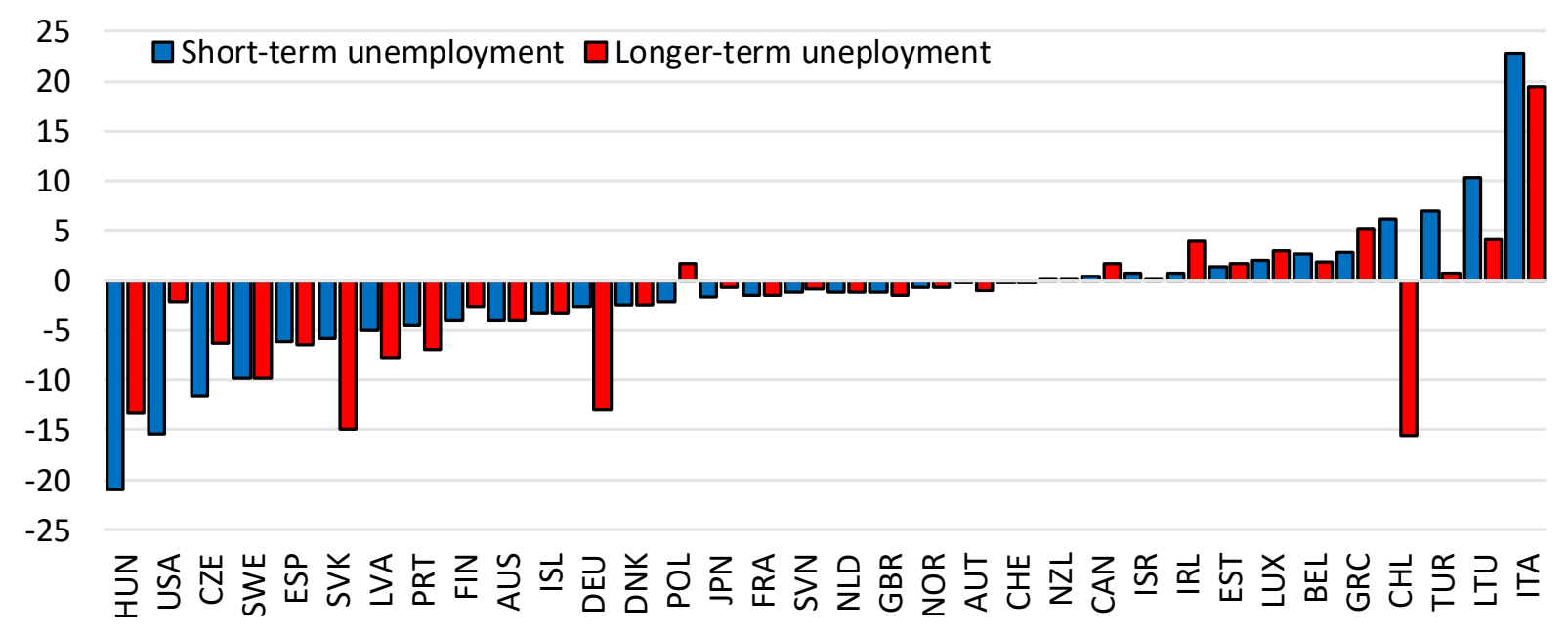

Note: The aggregate net replacement rate in case of short-term unemployment is computed as the simple average of the aggregate net replacement rate for an unemployment duration of six months and 12 months. The aggregate net replacement rate in case of long-term is the aggregate net replacement rate for an unemployment duration of two years. The change in the aggregate net replacement rate is computed as the difference between the value in 2018, or in the latest available year, and the value in 2001, or in the earliest available year. The aggregate net replacement rate for a specific unemployment duration is computed as a weighted average of the net replacement rate for the eight representative household types, where the weight of each household type reflects the average share in total population over the period 2001-18. Source: 2019 OECD Social Protection and Well-being database; 2019 OECD Income Distribution database; and authors' calculations.

\section{What can be done to make automatic fiscal stabilisers more effective?}

13. Several options to boost the effectiveness of automatic fiscal stabilisers exist, both on the revenue and expenditure sides. Some of them relate to increasing unemployment benefits or direct payments to individual during severe recessions, based on automatic macroeconomic triggers like the unemployment rate (Andersen, 2016; Boushey et al., 2019; Sahm, 2019). Such asymmetric stabilisers are particularly desirable when monetary policy is less effective in accommodating deep downturns, reflecting limited scope to cut policy interest rates due to the zero lower bound (Eichenbaum, 2019; Blanchard and Summers, 2020) and low sensitivity of private consumption and investment to changes in interest rates due to prevailing uncertainty.

14. The options discussed differ with regard to effectiveness, difficulty of implementation and potential undesirable side effects, primarily related to disincentives to work but also potentially reduced control over public finances - as discussed in the next section - and in some cases a potential to delay a needed structural labour reallocation. General principles of these options are discussed below together with their pros and cons. Implementation of policy reform proposals should account for a country-specific context and preferences regarding other important policy objectives of tax and benefit systems. 


\subsection{Increasing the timeliness of automatic fiscal stabilisers}

15. One option to boost automatic fiscal stabilisers with little changes to disincentives to work is to ensure their timeliness. In the case of taxes that affect household disposable income, and also corporate profits, it is important that they are paid at a high frequency so that they can react promptly to shocks to pre-tax income and thus limit their pass-through to disposable income. For instance, the introduction of the pay-as-you-earn (PAYE) tax system for PIT in France in 2019 has likely boosted automatic fiscal stabilisers compared with the old tax system, where income taxes were settled one year after the income was earned. The PAYE tax system is currently the norm in most OECD countries, with different modalities of withholding taxes.

16. Linking immovable property taxes to market prices could also strengthen automatic fiscal stabilisers by reducing tax burdens during recessions and increasing them in good times. ${ }^{13}$ However, the effectiveness of immovable property taxes as automatic stabiliser may be small. They account for only around $1.5 \%$ of household disposable income in the median OECD economy (slightly more in Canada, France and the United Kingdom - around 4-5\%) despite their rise in most OECD countries over the past two decades (OECD, 2019). Moreover, the ensuing impact on household consumption could be muted if the taxes are paid primarily by wealthy and liquid households who have low marginal propensity to consume. Also, linking immovable property taxes closely to the housing cycle may involve undesirable side effects. It could induce pro-cyclicality of local government spending if balanced budget rules bind and if these taxes are an important revenue for local governments. This could be a big problem as the variation of real estate prices over the cycle can be very large. ${ }^{14}$ As property taxes are usually paid once a year, they are not going to be timely either. Maintaining and updating property prices can be costly and inaccurate valuations may affect social fairness negatively (Almy, 2014).

\subsection{Changing the tax system}

17. PIT is a powerful automatic stabiliser and making it more progressive has the potential to boost its stabilisation property considerably (Box 2). OECD countries differ with regard to the strength of automatic stabilisation via PIT (Figure 7) and there is scope to strengthen it in economies with less progressive tax systems and low top tax rates. Countries could also increase the number of brackets to boost the tax elasticity (Box 2). Currently, the median OECD country has five brackets, with at least twice as many in Luxembourg, Mexico and Switzerland (Figure 7).

18. However, PIT reforms may impact other important policy objectives, including raising tax revenues, stimulating economic growth or enhancing the redistributive impact of the tax system, and often involve a trade-off between equity and efficiency. For instance, while PIT rate increases in the upper income brackets strengthen progressivity and fairness, they might also reduce economic incentives to work, save and invest (OECD, 2019).

\footnotetext{
${ }^{13}$ In many OECD countries, immovable property taxes were based principally on property prices; Belgium, France and Italy used rental value basis; and several countries applied a mixture of various valuation methods (Almy, 2014). The frequency of updating property values or rents varied too. Iceland and the Netherlands revalued prices on an annual basis; some countries, including Austria, Estonia and the United Kingdom, did not have legal requirement to revalue prices at all; and some used a form of indexation linked not only to property prices but also to consumer prices and construction costs (Almy, 2014).

14 This challenge could be addressed by introducing tax floors and caps to prevent excessive tax burdens during housing booms and too small revenues during housing busts. However, such fixes would also limit the automatic stabilisation properties.
} 
Figure 7. Personal income tax systems differ across OECD countries

\section{A. Measure of personal income tax progressivity ${ }^{1}$}

25

\section{$\uparrow$ stronger automatic stabilisers}

20

15

10

5

0

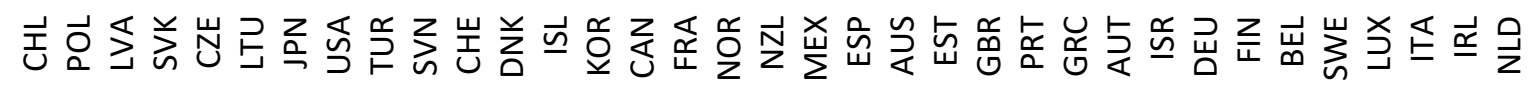

B.Top tax rate

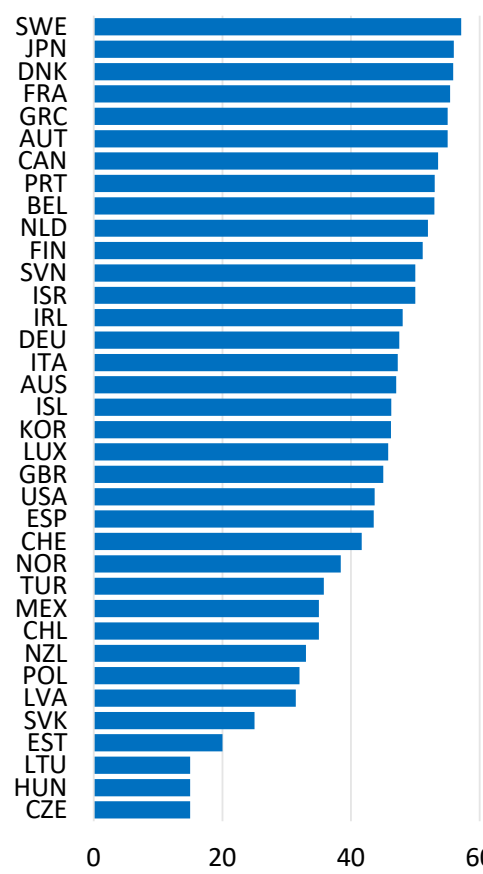

C. Threshold

(expressed as a multiple of the average wage)
D. Number of tax brackets ${ }^{2}$
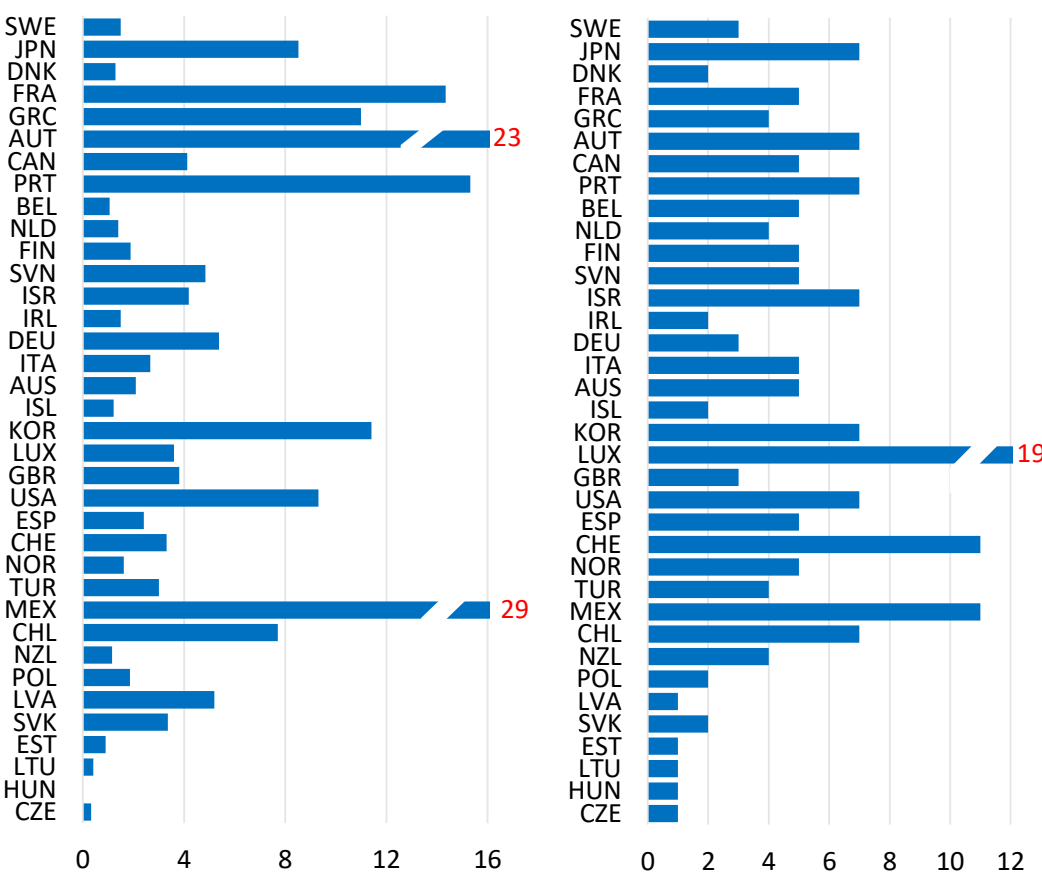

1. The measure of PIT progressivity refers to the difference in the tax rate for single person without children at $67 \%$ and $167 \%$ of average wage as of 2018. The tax rate is calculated as the tax burden in relation to gross wage earnings. Positive values indicate that the average tax rate is higher for individuals with higher income ( $167 \%$ of average wage) than for individuals with lower income ( $67 \%$ of average wage), implying that the tax system is progressive. This indicator is based on one family type (single person without children) and thus may not be representative for the entire tax system (Section 2.1).

2. In the Czech Republic, Estonia, Hungary, Latvia and Lithuania a linear tax is applied (countries with one tax bracket). Note: Panels B-D: As of 2018.

Source: OECD Taxing Wages database; and authors' calculations. 


\section{Box 2. Determinants of the elasticity of direct taxes on households with respect to income}

Estimating an exact aggregate elasticity of direct tax revenues, and thus the effectiveness of relevant automatic fiscal stabilisers, is challenging. This reflects complex interactions among the tax code (the number and level of tax brackets and associated marginal tax rates), taxable income distribution and the size and distribution of shocks to taxable income. These factors affect tax elasticities of individual taxpayers, which are determined by the ratio of the marginal tax rate to the average tax rate (Price et al., 2015), and thus the aggregate tax elasticity. This box sheds some light on these interactions with a help of stylised simulations.

\section{Progressivity of personal income taxes}

In general, the tax elasticity increases with the overall progressivity of the tax system. With a linear tax system (with no tax exemptions), the elasticity is one - i.e. taxes change by the same percentage as gross income. In this case, direct taxes do not help much to offset the market income decline (disposable income falls by the same percentage as market income) and they do not contribute to the semi-elasticity (Box 1). Still, after a negative shock to market income, direct taxes would decline in absolute amount and the measure of effectiveness of automatic fiscal stabilisers used by Maravalle and Rawdanowicz (2020) would be small but greater than zero. In contrast, with a progressive tax system, the same income shock results in a larger decline in income tax revenues, i.e. an elasticity higher than one, as some taxpayers due to their reduced income are taxed at lower rates. As shown in a stylised simulation, moving from the linear tax system to a very progressive one (with the top marginal tax rate of $85 \%$ ) could almost double the tax elasticity and the measure of the effectiveness (Figure 8, Panel A) and widen the Gini coefficient difference between gross and net income (Figure 8 , Panel B). ${ }^{1}$ Thus, countries with more redistributive tax systems should have more effective automatic fiscal stabilisers.

\section{Figure 8. Relation between tax progressivity and the strength of automatic fiscal stabilisers}

A Strength of automatic stabilisers

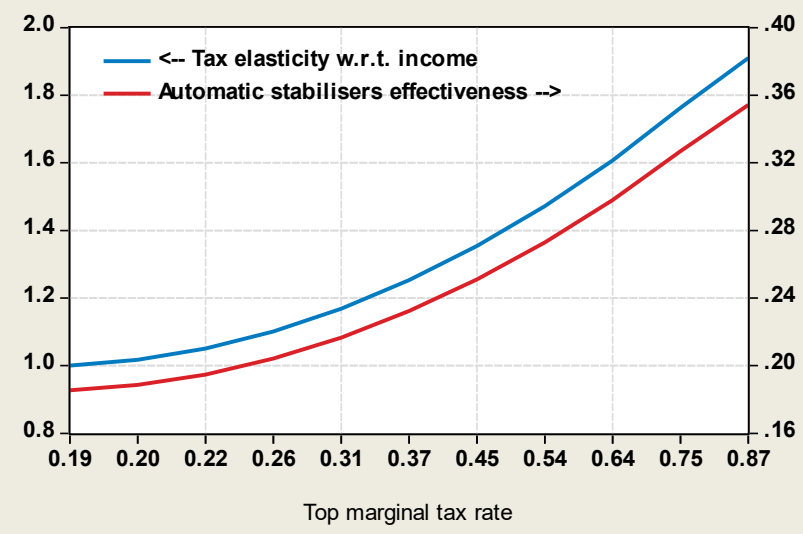

B. Gini for gross and net income

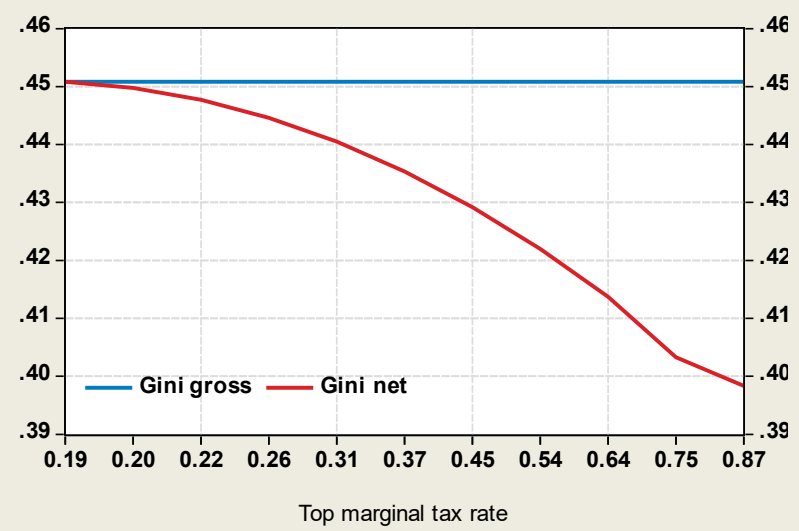

Note: Based on stylised simulation assuming five tax brackets and marginal rates, and a market income distribution generated by a polynomial with a Gini coefficient of around 0.45 . A stylised increase in the progressivity, starting from the linear tax, is achieved by lowering the first and second marginal tax rates and by increasing the third, fourth and fifth marginal tax rates so as to keep the total tax revenue unchanged (tax bracket thresholds are kept constant). A $5 \%$ decline in wages for all taxpayers is assumed for the calculation of the tax elasticity and the effectiveness of automatic fiscal stabilisers. The latter is defined as a level change in direct taxes divided by a level change in wages - see Maravalle and Rawdanowicz (2020). In Panel B, the Gini coefficient takes values between 0 for full equality (all taxpayers receive the same income) to 1 for full inequality (one taxpayer receives all income).

Source: Authors' calculations. 


\section{Tax bracket thresholds}

For a given unequal distribution of income and a zero marginal tax rate for the first tax bracket, a proportional decline in tax thresholds lowers the elasticity and vice versa. ${ }^{2}$ This reflects two effects. First, the average tax rates in the top brackets go up relative to the marginal rates as the prevailing marginal tax rates apply to a higher share of income for top brackets. Second, the weight of the upper tax brackets in calculating the aggregate elasticity increases. This implies that not indexing tax bracket thresholds to wage inflation regularly (the so-called fiscal drag) can result over time in a lower tax elasticity and thus less effective automatic fiscal stabilisers.

\section{Income shock, income distribution and tax brackets}

The impact of an income shock on the tax elasticity depends on the income distribution within and among tax brackets. In principle, a shock that shifts a large share of taxpayers to a different tax bracket will have a larger impact on the elasticity. This is more likely for big income shocks or when taxpayers are more concentrated in the vicinity of the tax bracket thresholds. Hence, the higher the proportion of taxpayers above but near the thresholds (for whom the ratio of the marginal to average rate tends to be higher), the higher the elasticity. This is more likely with a larger number of tax brackets. There may also be non-linear effects. For instance, if incomes are concentrated just below tax bracket thresholds, the tax elasticity in case of a negative income shock is inferior to the elasticity with a positive shock. Stylised simulations suggest that quantitatively the size of income shock, for a given income distribution and given tax brackets, does not affect the elasticity much when the shock is uniform across the income distribution (Figure 9).

\section{Figure 9. Relation between the size of shock and the strength of automatic fiscal stabilisers}

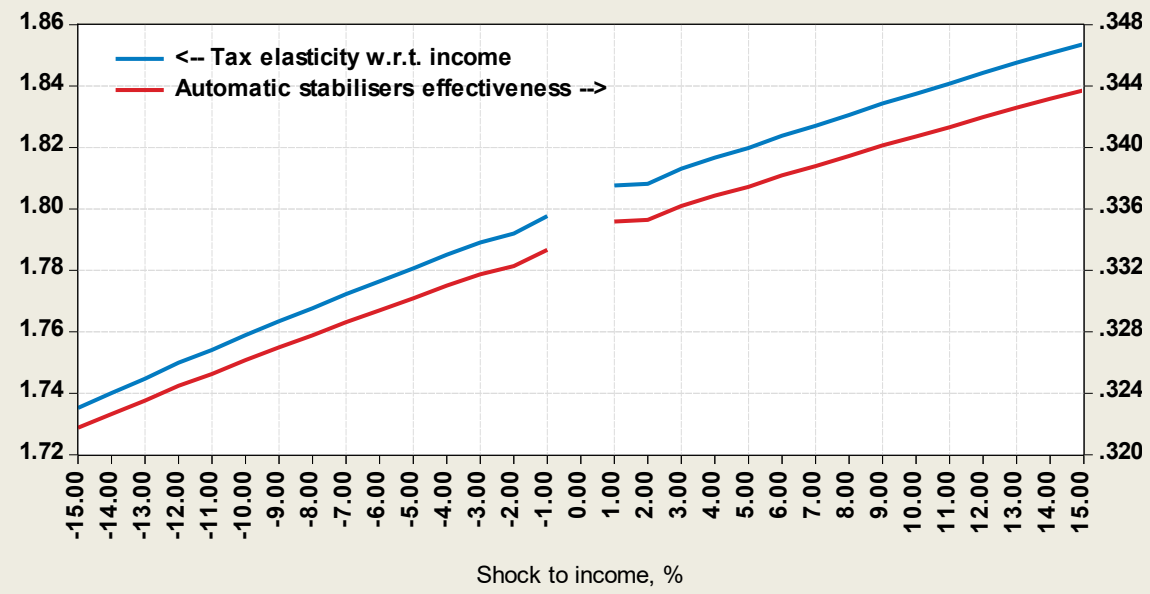

Note: Based on stylised simulation assuming five tax brackets and marginal rates, and a market income distribution generated by a polynomial with a Gini coefficient of around 0.45 . The same decline in wages for all taxpayers is assumed for the calculation of the tax elasticity and the effectiveness of automatic fiscal stabilisers. The latter is defined as a level change in direct taxes divided by a level change in wages - see Maravalle and Rawdanowicz (2020).

Source: Authors' calculations.

\section{Income inequality and automatic fiscal stabilisers effectiveness}

Higher income inequality for a given constant average wage reduces the tax elasticity. Higher wages and more taxpayers in top brackets relative to taxpayers in lower tax brackets (leading to a more unequal income distribution) result in a decline in the ratio of marginal rates to average rates in the top brackets and thus in the overall tax elasticity. However, according to stylised simulations, the impact is not very 
pronounced (Figure 10). In contrast to the tax elasticity, the measure of the effectiveness of automatic fiscal stabilisers increases with higher income inequality. This reflects the fact that the gap in the level of tax revenues without and with the wage shock grows in absolute terms as the value of taxes in both cases increase with higher wage inequality, while the level difference in aggregate wages between the two cases remains constant.

\section{Figure 10. Relation between income inequality and the tax elasticity}

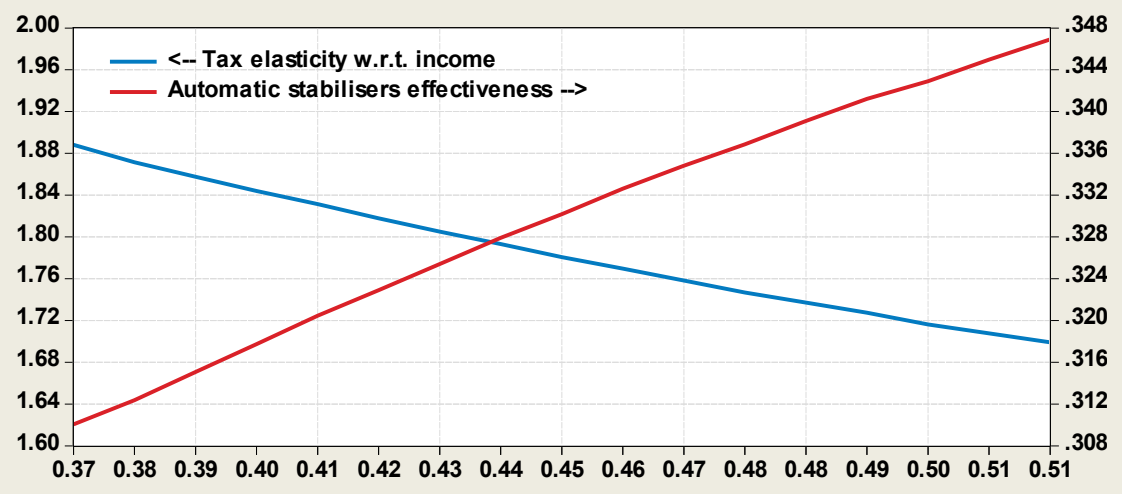

Gini coefficient for gross income

Note: Based on stylised simulation assuming five tax brackets and marginal rates, and a market income distribution generated by a polynomial with a Gini coefficient of around 0.45. Aggregate income, marginal tax rates and tax bracket thresholds are kept constant. Consequently, a more unequal income distribution implies a higher average tax rate, which lowers the aggregate elasticity. A 5\%-decline in wages for all taxpayers is assumed for the calculation of the tax elasticity and the effectiveness of automatic fiscal stabilisers. The latter is defined as a level change in direct taxes divided by a level change in wages - see Maravalle and Rawdanowicz (2020). The Gini coefficient takes values between 0 for full equality (all taxpayers receive the same income) to 1 for full inequality (one taxpayer receives all income).

Source: Authors' calculations.

1. This effect is weaker for a less unequal initial distribution of market income. A proportional change in all marginal tax rates (i.e. by the same percent) does not change the tax progressivity and thus does not affect the elasticity but it does affect the measure of effectiveness. If marginal rates are higher in top tax brackets than in lower tax brackets, increasing all marginal tax rates by the same amount (i.e. percentage points) reduces the elasticity by making the tax system less progressive, and vice versa.

2. The increase in tax brackets raises the elasticity only to a point where the rising weight of the first tax bracket with the zero tax rate dominates the falling weight of top brackets with the rising average tax rate.

19. Shifting some tax burden from social security contributions to PIT, which is usually more progressive, could also increase fiscal automatic stabilisation of household disposable income. The elasticities of employee social security contributions with respect to earnings are lower than for direct taxes on households (Figure 11) and thus work less well as automatic fiscal stabilisers. This reflects the fact that in most countries employee social security contributions are regressive - the rates either do not change with income (are linear), implying the elasticity of 1 , or they are paid at a fix rate up to a statutory ceiling, implying the elasticity of below $1 .{ }^{15}$ Moreover, in several OECD countries (including Germany, Japan, the Netherlands and Switzerland), social security contributions paid by employees are larger than direct taxes (Figure 12, Panel A). Such shift in the tax structure would have a direct positive effect on the semi-elasticity

15 In the latter case, the elasticity will fall with a positive income shock when the statutory ceiling applies. In contrast, it will increase when a negative income shock makes the statutory ceiling stop applying. 
and the measures of automatic fiscal stabilisers. Obviously, any such reform of social security contributions should consider possible negative consequences, like a weakened link between entitlements and contributions to social insurance programmes (including pensions), and ways to address them.

Figure 11. Personal income taxes are more elastic than social security contributions

The elasticity with respect to earnings

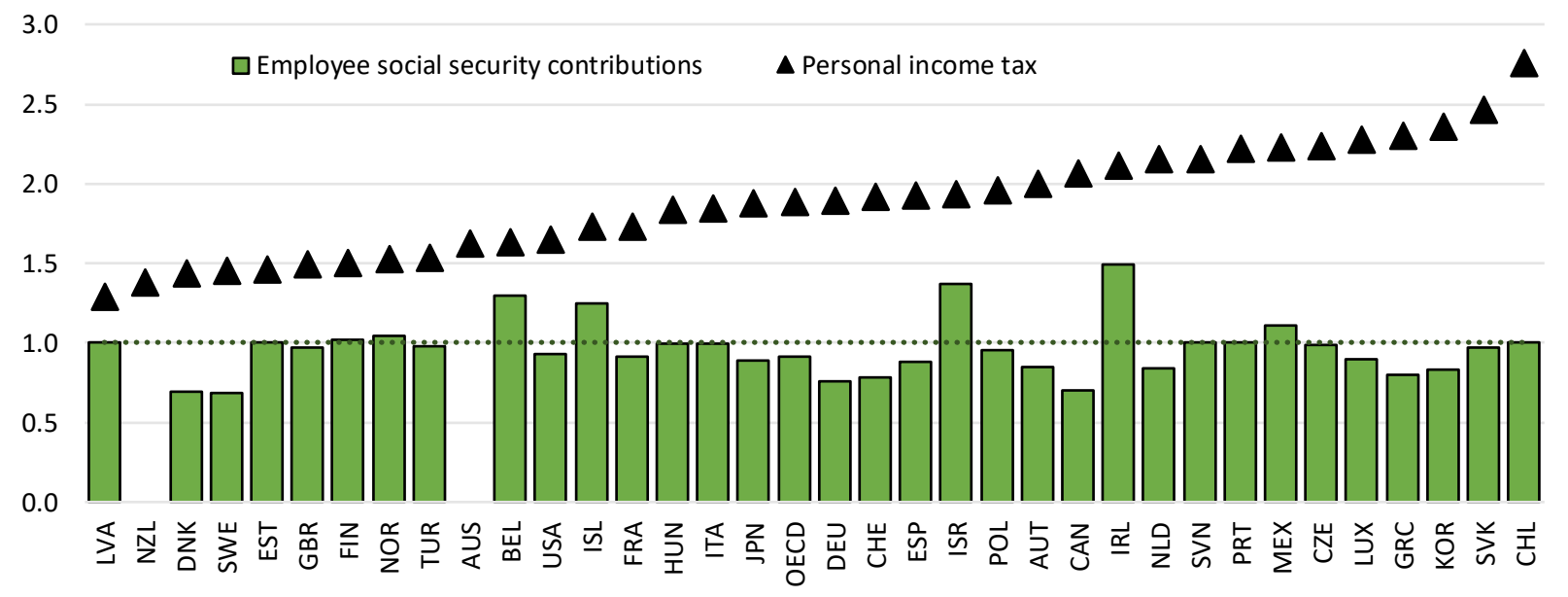

Note: The horizontal dotted line marks the elasticity of 1.

Source: Price, R., T. Dang and J. Botev (2015), "Adjusting fiscal balances for the business cycle: New tax and expenditure elasticity estimates for OECD countries", OECD Economics Department Working Papers, No. 1275.

Figure 12. Social security contributions and indirect taxes are larger than direct taxes on households in many OECD countries

A. Difference between SSC and household direct taxes As a ratio to household direct taxes

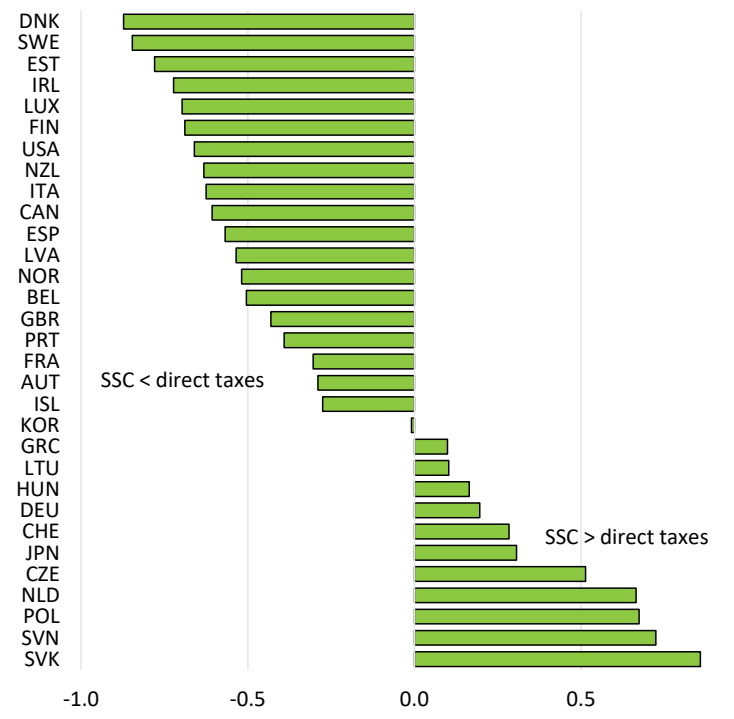

B. Difference between indirect taxes and household direct taxes As a ratio to household direct taxes

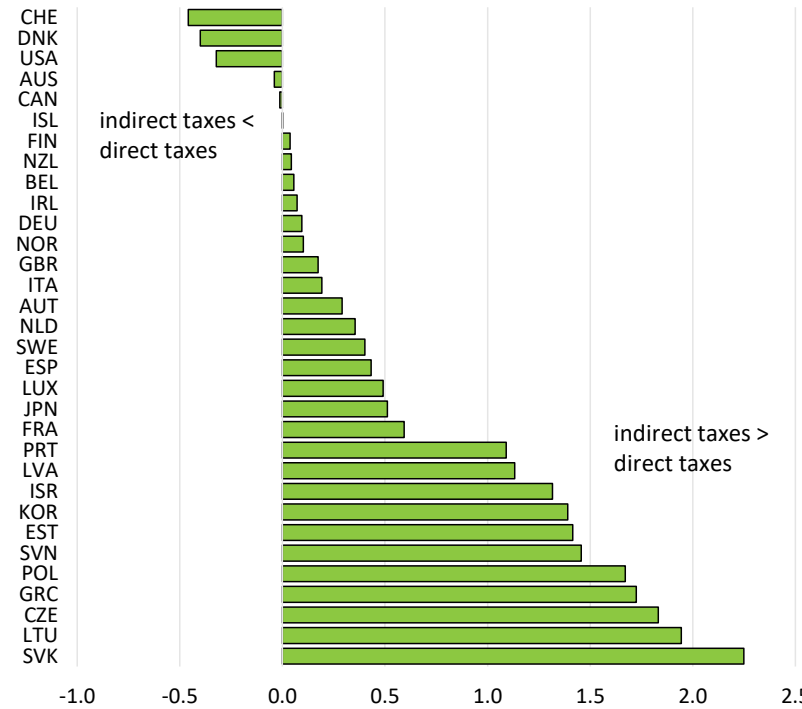

Note: SSC is social security contributions paid by employees. Indirect taxes refer to taxes on production and imports (they include value added taxes). Based on average levels between 2014 and 2018.

Source: OECD Economic Outlook 106 database; and authors' calculations. 
20. In a similar vein, shifting the tax structure to rely less on indirect taxes and more on direct taxes on households could boost automatic stabilisation of fiscal policy and result in a higher semi-elasticity. The tax elasticity of indirect taxes with respect to private consumption is smaller than the elasticity of PIT with respect to earnings, ${ }^{16}$ and in the majority of countries indirect taxes are larger than direct taxes on households (Figure 12, Panel B). ${ }^{17}$ Moreover, indirect taxes do not affect household disposable income. However, as discussed above, higher burdens of direct taxes can have undesirable longer-term effects on growth, whereas there is no significant association between standard VAT rates and long-term growth (Akgun et al., 2017).

\subsection{Improving the unemployment benefit system}

21. Unemployment benefits contribute significantly to the stabilisation of household disposable income (Section 1.2). Their effectiveness differs across the OECD countries, reflecting the generosity and eligibility of unemployment benefits (Figure 13). Thus, in principle, in countries with weaker unemployment support, automatic stabilisation can be increased by modifying existing unemployment benefits. This may, however, reduce the incentive to work by weakening job search efforts and rising reservation wages and thus leading to persistence of unemployment (Ljungqvist and Sargent, 1995, 1998; OECD, 2011b). The side effects stemming from moral hazard and adverse selection because of unemployment insurance may not be strong if the generosity of the insurance is combined with effective activation policies, including from eligibility conditions requiring active job searching and participation in education and activation programmes (Andersen, 2016; OECD, 2018; Hijzen and Salvatori, 2020), and where current benefits are below optimal levels (Mirrlees, 1971; Baily 1978; Varian, 1980).

\section{Figure 13. The degree of unemployment protection decreases with its duration}

Aggregate net replacement rate in 2018 for different duration of unemployment, \%

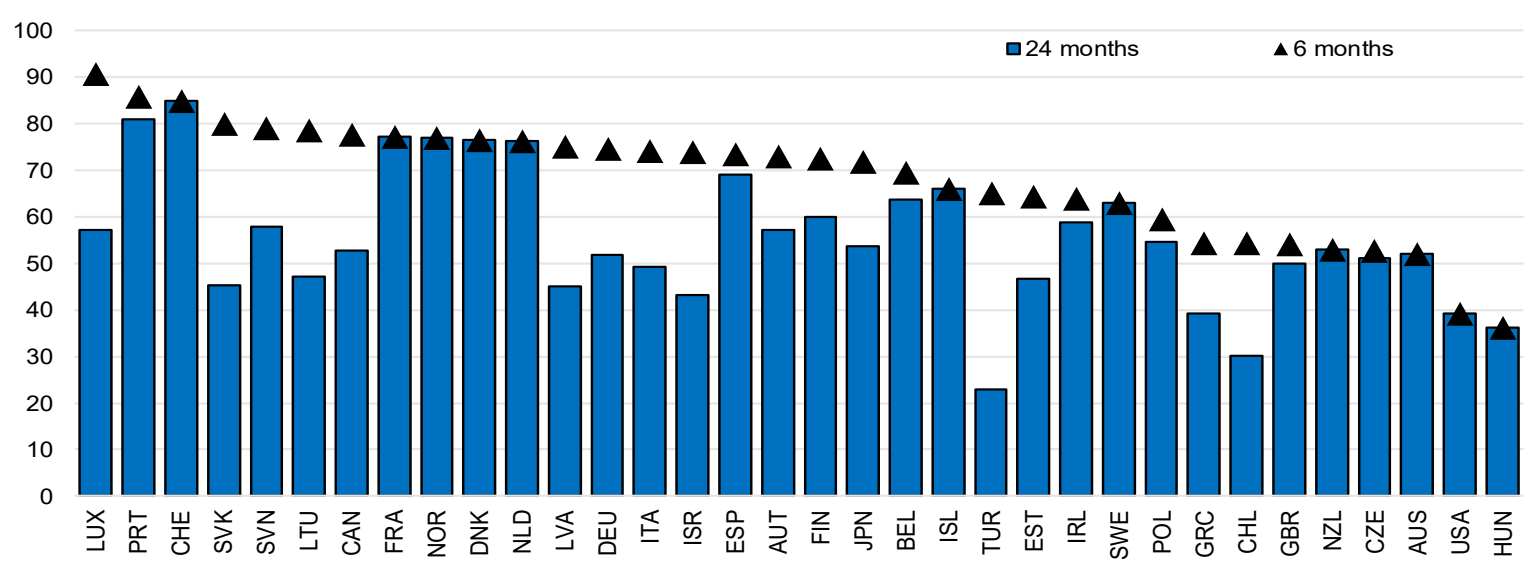

Note: The aggregate net replacement rate is a weighted average of the net replacement rates of eight household types. The net replacement rate of a given household type is defined as the ratio of net income while out of work divided by net income while in work. Thus, it measures the fraction of net income in work that is maintained when becoming unemployed. For household types with at least two members, it is computed assuming that only one household member changes its working status with the other(s) maintaining both their earnings and working status. The weights refer to average shares of a specific household type in total population over 2000-18.

Source: 2019 OECD Social Protection and Well-being database; 2019 OECD Income Distribution database; and authors' calculations.

\footnotetext{
${ }^{16}$ In three-quarters of OECD countries, the indirect tax elasticity with respect to the output gap/private consumption is below 1.1 and, in one third of these countries, the elasticity is below 1 (Table 7 in Price et al. (2015)).

17 Indirect taxes include value added type taxes, taxes and duties on imports excluding VAT, import duties, taxes on imports excluding VAT and duties, export taxes, taxes on products, excluding VAT, import and export taxes. VAT account for $60 \%$ on average across the OECD countries.
} 
22. Automatic stabilisation via unemployment benefits could be further boosted by increasing the generosity of unemployment benefits, including eligibility criteria, conditional on the extent and duration of a negative shock (Andersen, 2016; Boushey et al., 2019). Counter-cyclical unemployment benefits ensure that they are provided when they are most socially valuable and when disincentives to work are weaker (Andersen, 2014). The business-cycle contingency should be based on macro triggers that are easy to measure and are published timely to reduce information lags. In this respect, the unemployment rate is a good candidate. Some solutions in this spirit exist for instance in Canada and the United States, and further options have been discussed for the United States (Boushey et al., 2019). ${ }^{18}$

- In Canada, eligibility conditions, the length of benefits and the level of allowances of the employment insurance scheme vary with the local unemployment rate. ${ }^{19}$ While the scheme is intended to make benefits more generous in areas of the country where it is harder to find work, a higher country-wide unemployment rate increases benefits everywhere as regional thresholds are fixed and do not change over time. The scheme targets benefits to local business cycle conditions, which bolsters the welfare of workers losing jobs and their families, without provoking an excessive financial burden on the nationwide scheme. However, the definition of economically relevant regions can be a thorny issue and approximating the local business cycle with a single indicator may be overly simplistic.

- In the United States, the Extended Benefits programme lengthens the duration of unemployment benefits in states experiencing high unemployment and who have exhausted their regular, state-provided unemployment benefits (Stone and Chen, 2014). ${ }^{20}$ The costs of the programme are normally split equally between states and the federal government, but the federal government fully funded the programme between 2009 and 2013. The US federal government also provided emergency benefits in the past recessions and the current COVID-19 crisis on an ad-hoc basis. ${ }^{21}$

\footnotetext{
${ }^{18}$ Chile also has two additional months of unemployment benefits if the unemployment rate is above the average of the last four years by at least 1 percentage point. In Poland, the duration of the benefit depends on regional disparities in unemployment rates: it doubles if the regional unemployment rate exceeds $150 \%$ of the average unemployment rate in the country.

19 The length of employment insurance benefits ranges from 14 weeks up to a maximum of 45 weeks depending on the local unemployment rate and the amount of insurable hours accumulated by the employment insurance claimant. The number of the highest earning weeks used to calculate the unemployment allowance also varies with the local unemployment rate. Regional unemployment rates refer to a three-month moving average of seasonally-adjusted local unemployment rates in 62 economic regions. The scheme was tailored to local economic conditions after the steep fall in commodity prices in late 2014. Between January 2015 and July 2017, the maximum duration of unemployment benefits in 15 economic regions affected by the drop in commodity prices was extended up to further 20 weeks of benefits for long-tenured workers.

20 The triggers are based on the current insured unemployment rate (number of beneficiaries over the total number of people working in jobs in which they are potentially eligible for unemployment benefits) or the current standard unemployment rate and their levels two years earlier (Stone and Chen, 2014). Depending on the definition of the trigger unemployment rate used and relevant thresholds, the length of standard unemployment benefits in most states of 26 weeks can be extended between up to 13 and 20 weeks.

21 During the global financial crisis, the Emergency Unemployment Compensation programme provided up to 34 weeks of federal benefits in all states and up to 53 weeks in states with unemployment rates at or above $8.5 \%$ for workers who exhausted their regular state-provided benefits (Stone and Chen, 2014). The Coronavirus Aid, Relief, and Economic Security (CARES) Act, signed on 27 March 2020, extended the duration of unemployment insurance benefits by 13 weeks; increased payments by USD 600 per week for three months; and loosened the eligibility criteria until end-2020 to include part-time workers, freelancers, independent contractors and self-employed and waved work
} 
23. Automatic stabilisation of unemployment benefits could be also bolstered by increasing the coverage rates, to the extent that they reflect inefficiency or inadequacy of existing unemployment support. The coverage rates of unemployment benefits are generally low across the OECD, with the pseudo-coverage rates indicating that, on average across the OECD countries, only one unemployed in three received unemployment benefits (OECD, 2018). ${ }^{22}$ Some of the decline in the coverage rates is the result of policy reforms that have reduced unemployment-benefit generosity either to make budgetary savings or to strengthen job-search incentives (OECD, 2018). Unemployment benefits are not designed to cover all unemployed, but if they cover increasingly fewer unemployed they will not play an important stabilisation function. ${ }^{23}$ If the low coverage reflects tight eligibility criteria or difficult administrative procedures that discourage applicants, rather than voluntary decisions of individuals (stemming from voluntarily foregoing due benefits or resigning from a job), then there is a scope to improve the automatic stabilisation role of unemployment benefits.

24. In response to the COVID-19 crisis, unemployment insurance was made more generous in most OECD countries on an ad-hoc and temporary basis (OECD, 2020a). This involved a temporary expansion of unemployment benefit eligibility criteria (Australia, Belgium, Israel, Italy, Lithuania, Poland, South Africa, Spain, Sweden and the United States), including their extensions to some categories of non-standard workers (Finland, Greece, Ireland, Italy and Spain); a lengthening of duration (Belgium, Germany, Greece, Luxembourg, Portugal, and the United States) and an increase in the size of benefits (Australia, Belgium, Brazil, France, Ireland, New Zealand, Sweden and the United States).

\subsection{Introducing automatic direct payments to individuals during recessions}

25. Sahm (2019) proposed to introduce direct lump-sum payments to individuals based on changes in the unemployment rate to increase the effectiveness and timeliness of fiscal stimulus in the United States. Large one-time payments tend to result in higher and quicker spending than when payments are smaller or disbursed over longer periods (Parker et al., 2013; Sahm et al., 2012). Being visible and timely, they are also likely to be more effective than some other automatic fiscal stabilisers. For instance, disproportionally lower direct taxes or lower interest payments would be spread along the year, possibly reducing the marginal propensity to consume from such disposable income gains. Sahm (2019) argued for universal payments irrespective of income as setting an income criterion would exclude some higher-income but illiquid individuals, while low-liquidity individuals tend to react faster to stimulus (Kaplan and Violante, 2014).

26. The overall amount of payments can be fixed as a share of nominal GDP prior to the shock and changes in the unemployment rate can be used as a trigger for lump-sum payments and a criterion to maintain payments in subsequent years (Sahm, 2019). ${ }^{24}$ The advantage of using the unemployment rate

history requirements (Kovalski and Sheiner, 2020). These measures were entirely financed by the federal government. However, the CARES Act did not cover states' regular unemployment insurance benefits.

22 The pseudo-coverage rate is the total number of unemployment benefit recipients relative to the total number of unemployed. In the United States, since the late 1950s, fewer than half of unemployed workers have actually received unemployment insurance, except during recessions (Stone and Chen, 2014); and there are big cross-state differences, ranging from 9\% in Mississippi to 57\% in Massachusetts as of 2019Q4 (Kovalski and Sheiner, 2020).

23 For instance, non-standard workers, defined as workers in temporary contracts, in part-time jobs and the selfemployed, represent on average across OECD countries around a third of total employment and are 40-50\% less likely to receive any form of income support during periods out-of-work than standard employees (OECD, 2019). 
is that it is timely and revised little compared with, for instance, GDP growth. In the United States, the proposed thresholds would have triggered payments shortly after the start of all the past seven recessions. To increase the effectiveness of such stimulus, the authorities should make the public aware of the payments and make necessary administrative preparations, well in advance before the next recession, to minimise the time needed to send money and to maximise benefits for the population. ${ }^{25}$

27. In response to the COVID-19 crisis, the US government introduced economic impact payments (EIP) to households as an emergency and one-off measure. EIP have provided a timely, even if modest, lump-sum support to household income. ${ }^{26}$ No action was required for most eligible households. EIP were not universal, as households earning a gross income above a certain threshold were excluded. While EIP are not automatic, they could be used timely in future recessions, complementing automatic fiscal stabilisers, or could be developed in a fully automatic and longer-lasting instrument as suggested by Sahm (2019). ${ }^{27}$

\subsection{Automatic fiscal stabilisers for businesses}

While the measures of automatic fiscal stabilisers discussed above mostly refer to households, policy options for boosting automatic fiscal stabilisers for businesses exist as well. They include improving their timeliness via reforms of the tax administration (e.g. accelerated VAT refund) and introducing or expanding a possibility for businesses to "carry back" net operating losses. This latter involves a refund of taxes paid in the past to cover current firm's net operating loss. In this respect, this tax treatment helps smooth corporate income, supports investment and reduces chances of business bankruptcies during a downturn, thus preventing potential longer-term negative effects on growth. Prior to the COVID-19 crisis, loss carry-backs existed only in few OECD countries, including in Germany, Ireland, Korea, the Netherlands and the United Kingdom with a limit to one year of past taxes (Hanappi, 2018; Ernst \& Young, 2019; Asen, 2020). In the United States, in response to the COVID-19 pandemic, the Coronavirus Aid, Relief, and Economic Security (CARES) Act temporarily suspended the restriction on carrying back losses and the limits on excess business losses for non-corporate taxpayers introduced in 2018 (Keightley, 2020). While loss carry-backs can act as an automatic stabiliser, this measure is prone to frauds (with difficulty to distinguish between true and "paper" losses); may not be very timely, given that businesses can benefit from it at the end of a fiscal year; and, in the United States, its effectiveness is found to be low (Keightley, 2020).

\section{Other policy measures to help economic stabilisation}

28. Other fiscal policy options exist that increase the stabilisation properties of the economy but that are not fully automatic. They include short-term work compensation schemes and active labour market policies and are discussed below.

\footnotetext{
25 Reaching all eligible US individuals quickly for some stimulus measures during the global financial crisis (Sahm, 2019) and the COVID-19 recession proved administratively challenging.

${ }^{26}$ Economic income payments amounted to USD 1,200 for individuals, USD 2,400 for married couples and up to USD 500 for each qualifying child. They totalled to more than USD 267 billion (1.25\% of 2019 GDP) and were distributed within two months from their announcement.

27 An increasing prevalence of such programmes would affect the standard measures of automatic stabilisers, in particular on the government spending side, making them non-linear depending on the phase of a cycle.
} 


\subsection{Short-term work compensation schemes}

29. Short-term work compensation schemes (known in Germany as Kurzarbeite) facilitate a flexible adjustment of working time of employees in case of negative shocks and partly compensate the ensuing loss of employees' income. The cost of the compensation schemes are shared between the state and firms to limit the risk of reducing labour market flexibility. The schemes are voluntary and thus not automatic and usually restricted in time. ${ }^{28}$ They help limit layoffs and sustain income, supporting job security and household consumption. ${ }^{29}$ Thus, state expenses on these schemes are partly compensated by limiting spending on unemployment benefits and the decline in tax revenues. The short-term work compensation schemes allow employers to retain firm-specific human capital during downturns and to limit a possible drop in productivity (Fujita and Moscarini, 2017; Fujita et al., 2019). Firms can also avoid costs of laying-off, especially when they are high due to stringent labour market regulation.

30. Short-term work compensation schemes involve, however, some drawbacks. Administrative burden is higher compared with many automatic fiscal stabilisers. They may also involve inefficiencies, particularly when shocks turn out to be permanent, related to too many employees working shorter hours, delaying the needed reallocation of resources (with implications for longer-term growth), and deterring new hires; and they do not always cover temporary workers (Cahuc, 2019).

31. Prior to the COVID-19 pandemic, short-term work compensation schemes existed in many OECD countries. Their parameters, including eligibility criteria, employers' costs and income compensation for employees, differed substantially. ${ }^{30}$ In general, the schemes were less developed in countries where it was easier to negotiate wages and hours worked at the company level (Boeri and Bruecker, 2011; Cahuc and Carcillo, 2011). The recourse to short-term work compensation schemes increased during the COVID-19 pandemic to fight employment consequences of the crisis. In countries where short-term work compensation schemes were already in place, they have been strengthened by simplifying and extending access conditions (Austria, Hungary, Italy, Luxembourg, Portugal and Spain), and increasing duration (Italy, Spain, Switzerland and Turkey) and the size of the government support (the Czech Republic, Japan and Hungary). In some other OECD countries (including Estonia, Greece, Ireland, Sweden and the United Kingdom), short-term wage compensation schemes have been introduced for the first time, often as a temporary and exceptional measure.

32. The effectiveness of short-term working schemes can be improved by increasing their timeliness. During the COVID-19 crisis, this has been achieved by accelerating administrative procedures, for instance by reducing the delay for public authority to approve a firm's request and for providing the subsidy after that the request has been authorised. ${ }^{31}$

\footnotetext{
${ }^{28}$ For instance, in Germany, they require an agreement between management and work councils. Moreover, the maximum duration is fixed at six months, but it can be extended by ministerial decree up to one year in the case of exceptional circumstances in the labour market in specific industries or regions, and up to two years in the case of country-wide deterioration in labour markets.
}

${ }^{29}$ Empirical evidence from the 2008-09 recession showed that short-time work compensation schemes have resulted in net job gains (Boeri and Bruecker, 2011; Cahuc and Carcillo, 2011; Hijzen and Venn, 2011), though some effects were temporary (Hijzen and Martin, 2013).

30 Before the COVID-19 crisis, they existed in Austria, Belgium, the Czech Republic, Denmark, Finland, France, Germany, Hungary, Italy, Japan, Luxembourg, the Netherlands, Norway, Poland, Portugal, the Slovak Republic, Spain, Switzerland and Turkey (Hijzen and Venn, 2011; Cahuc, 2019).

31 In France, the maximum delay for public authority to accept participation in the short-time working scheme was shortened to two days from a fortnight. In Spain, the delay was reduced to five days. In Italy, a quicker disbursement 
33. Some countries, in response to the COVID-19 crisis, implemented temporary wage subsidy schemes rather than short-term wage compensation schemes as a job retention policy. ${ }^{32}$ Under such schemes, a firm receives a subsidy when experiencing a significant decline in revenue or sales and not in working hours. Firms can use these transfers to pay wages to workers whose working time is temporarily reduced or who do not work, as it happens with short-term work compensation schemes. Temporary wage subsidies involve less administrative burden for firms and may provide stronger incentives to increase hours worked quickly when conditions improve (OECD, 2020b).

\subsection{Active labour market policies}

34. Spending on active labour market policies (ALMP) could act as a stabilisation measure as they help increase the chances that the unemployed will find new jobs. Effective ALMP could thus help reduce unemployment benefit spending. They could also allow countries to have more generous unemployment benefits and ensuing more effective automatic fiscal stabilisers without creating too much employment disincentives (see above). In addition, ALMP can be useful to address unemployment problems in specific sectors and groups at risk of marginalisation (low-skilled, old or migrant workers), especially when aggregate stabilisation policies do not ensure sectoral employment stabilisation (Andersen, 2016).

35. Average spending on ALMP is small in relation to GDP, with the median of around $0.5 \%$ of GDP in 2013-17, ranging from around $0.1 \%$ of GDP in Australia, Japan and the United States to $1-2 \%$ in some Scandinavian countries (Figure 14, Panel A). ALMP spending is not strongly correlated with the economic cycle in most OECD countries (Figure 14, Panel B), even if in principle it reacts to labour market conditions in an automatic or quasi-automatic way in a number of countries, including Australia, Denmark and Switzerland (Immervoll and Scarpetta, 2012; OECD, 2018). ${ }^{33}$ This implies that spending per unemployment tends to decline in recessions.

36. In this context, making spending on ALMP more automatic is desirable. However, its effectiveness is difficult to assess, reflecting uncertainties about ALMP effects on employment (OECD, 2005; Card et al., 2010). The implementation of an automatic rule for ALMP spending could involve challenges with translating funding increases into higher capacity at a short notice (OECD, 2018). Some effectiveness gains could be achieved by changing the composition of ALMP programmes, with some evidence suggesting that on-the-job training is more effective than, for instance, public-sector job creation programmes, private-sector employment subsides, self-employment support and start-up incentives (Immervoll and Scarpetta, 2012).

\footnotetext{
of the wage subsidy was achieved by allowing the authority entitled to receive the firms' request also to advance $40 \%$ of the total funds authorised under the short-time working scheme.

32 Temporary wage subsidy schemes have been used during the COVID-19 crisis by Canada, Estonia, Ireland, the Netherlands and Poland; in some of these countries, on top of the short-term wage compensation schemes (OECD, 2020b).

${ }^{33}$ ALMP expenditures are positively correlated with unemployment in around three quarters of the OECD countries, but only in one third of the countries the correlation is larger than 0.4 (Figure 14, Panels A and B). The link with unemployment is partly related to requirements that unemployed participate in re-employment programmes. In Denmark and Switzerland, adequate resources are earmarked in the budget every year based on expected unemployment (Immervoll and Scarpetta, 2012).
} 


\section{Figure 14. Spending on active labour market policies (ALMP)}

A. Average spending on ALMP 2013-17

$\%$ of GDP

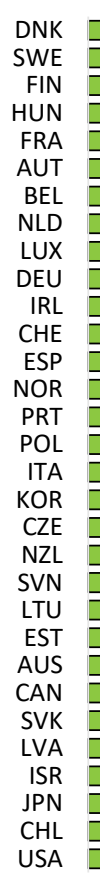

0.0

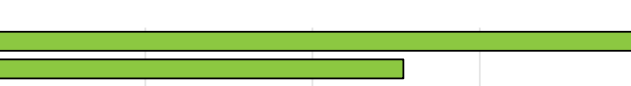

B. Correlation between percentage changes in unemployment and ALMP

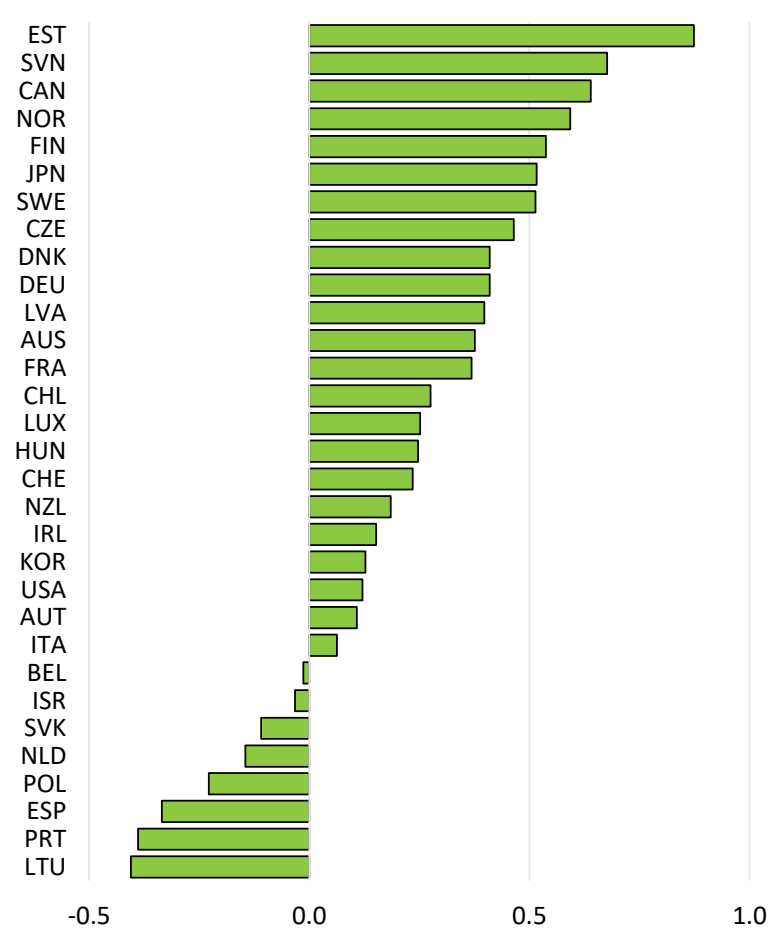

Source: OECD Economic Outlook 106 database; OECD Active Labour Market Policies database; and authors' calculations.

\section{Fiscal space and automatic fiscal stabilisers}

37. Full and smooth operation of automatic fiscal stabilisers will crucially depend on sufficient fiscal space. Even if automatic stabilisers are very effective in stabilising household disposable income and consumption, during a long recovery where the output gap remains negative for a protracted period, they might not be of much help if governments are forced to offset them via discretionary measures to prevent the ensuing deterioration in the budget balance that could undermine investors' confidence in public debt sustainability. Thus, it is essential that countries avoid having excessive deficits and high debt for a prolonged period. While assessing thresholds for debt sustainability precisely is difficult (IMF, 2013; European Commission, 2014), there are many past examples of countries offsetting automatic fiscal easing with discretionary tightening. Based on the OECD cyclical adjustment methodology (Price et al., 2015), for nearly half of OECD countries, half of the time between 1980 and 2018 automatic fiscal easing was accompanied by discretionary tightening. ${ }^{34}$ Besides, when fiscal sustainability is at risk, countries may need to sustain low budget deficits for a prolonged period, limiting room for fiscal manoeuvre. For instance, in view of its high government debt, Italy maintained between 2009 and 2018 a high structural primary

${ }^{34}$ This is based on annual changes in the underlying primary balance and the cyclical component that are bigger than $0.2 \%$ of potential GDP. This size threshold is used to reflect potential inaccuracies of the cyclical adjustment. They may stem, among other things, from using constant elasticities of specific taxes and spending with their respective bases as well as constant elasticities of relevant bases with respect to GDP growth (these elasticities have likely changed over time). 
budget surplus (2.9\% of potential GDP on average) despite a negative cyclical component of on average $1.9 \%$ of potential GDP over the same period.

38. In a downturn, providing a stimulus via automatic fiscal stabilisers is usually preferred over discretionary measures as the former should be temporary and thus have a less persistent negative impact on government debt (Blanchard et al., 2010; Sutherland et al., 2010). However, in practice, such advantage may not be always evident. Discretionary stimulus measures can be difficult to reverse politically and thus they can weigh on the budget for a long period. However, for instance, many discretionary stimulus measures in the global financial crisis were temporary by design. Moreover, negative output gaps tend to be persistent and so the negative contributions of the cyclical component to the primary balance. Between 1980 and 2018, in the median OECD economy, output gaps were estimated to be negative $60 \%$ of the time, and cumulative negative output gaps were considerably larger than cumulative positive output gaps in the majority of the OECD countries over this period. ${ }^{35}$ Negative output gaps and cyclical components of primary balances were particularly persistent and large in hard-hit OECD economies since the global financial crisis (Figure 15). Thus, one possible drawback of very large automatic fiscal stabilisers is that governments could have less control over the overall budget balance. This may lead to more frequent offsets of a cyclical balance deterioration with discretionary measures, especially in countries with fiscal vulnerability.

\section{Figure 15. Cumulative negative output gaps over a business cycle can be very large}

Sum between 2005 and 2018, per cent of potential output

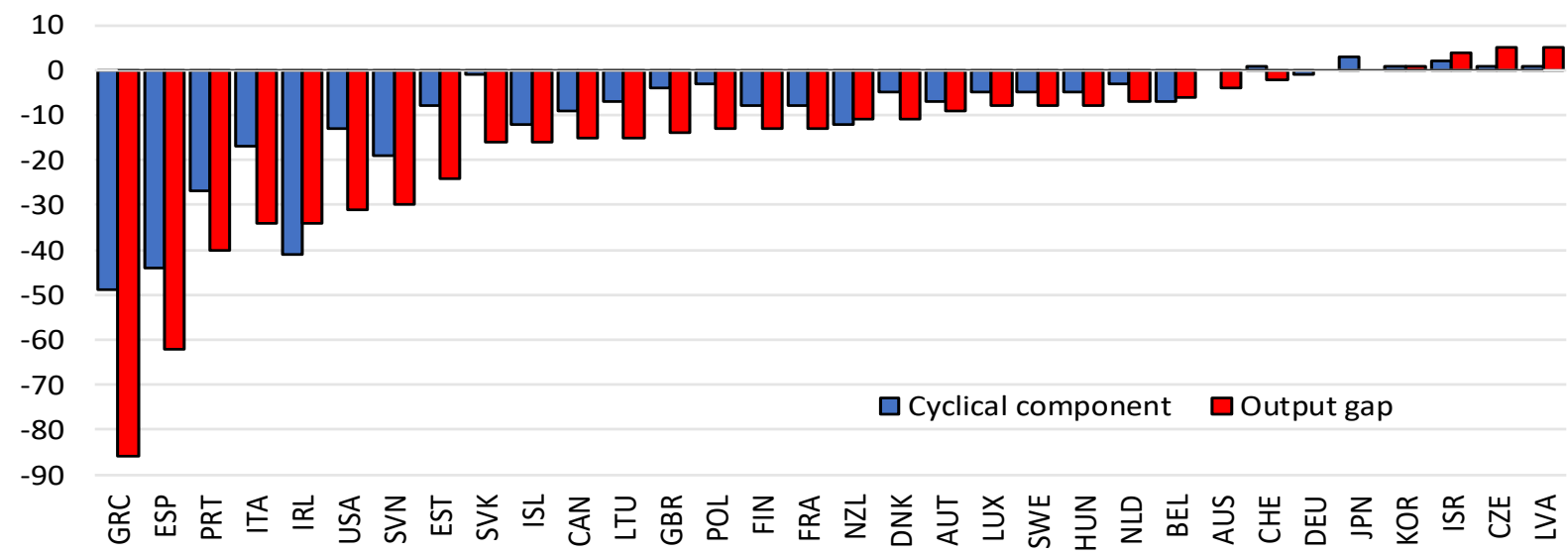

Note: The cyclical component is the difference between the primary balance and the underlying primary balance (i.e. the primary balance corrected for the cycle and one-offs).

Source: OECD Economic Outlook 106 database; and authors' calculations.

\footnotetext{
${ }^{35}$ When excluding the period since the global financial crisis (1980-2007), output gaps were negative $54 \%$ of the time and cumulative negative output gaps were larger than cumulative positive output gaps in more than half of the analysed countries.
} 


\section{Bibliography}

Akgun, O., B. Cournède and J. Fournier (2017), "The effects of the tax mix on inequality and growth", OECD Economics Department Working Papers, No. 1447, OECD Publishing, Paris. https://doi.org/10.1787/c57eaa14-en

Almy, R. (2014), "Valuation and Assessment of Immovable Property", OECD Working Papers on Fiscal Federalism, No. 19, OECD Publishing, Paris, https://doi.org/10.1787/5jz5pzvr28hk-en.

Andersen, T.M. (2014), "Tuning unemployment insurance to the business cycle", IZA World Labour, 2014:54.

Andersen, T.M. (2016), "Automatic stabilizers - The intersection of labour market and fiscal policies", IZA Journal of European Labour Studies, 5:11. https://doi.org/10.1186/s40174-016-0061-6

Asen, E. (2020), "Net Operating Loss Carryforward and Carryback Provisions in Europe", Tax Foundation, 13 February.

Auerbach, A. and D. Feenberg (2000), "The Significance of Federal Taxes as Automatic Stabilizers," Journal of Economic Perspectives, 14(3), 37-56.

Blanchard, O. and L. Summers (2020), "Automatic Stabilisers in a Low-Rate Environment", AEA Papers and Proceedings, 110: 125-30.

Blanchard, O., G. Dell'Ariccia and P. Mauro (2010), "Rethinking macroeconomic policy", Journal of Money, Credit and Banking, 42 (s1), 199-215.

Boeri, T. and H. Bruecker (2011), "Short-time work benefits revisited: Some lessons from the great recession”, Economic Policy, 26:68, 697-765.

Boushey, H., R. Nunn and J. Shambaugh (eds), Recession Ready: Fiscal Policies to Stabilize The American Economy, report, the Hamilton Project, Washington Center for Equitable Growth.

Cahuc, P. (2019), "Short-time work compensation schemes and employment", IZA World of Labor, 2019: 11. doi: 10.15185/izawol.11.v2

Cahuc, P. and S. Carcillo (2011), "Is short-time work a good method to keep unemployment down?" Nordic Economic Policy Review, 1:1, 133-164.

Card, D., J. Kluve and A. Weber (2010), "Active labour market policy evaluations: a meta-analysis", The Economic Journal, 120(548), F452-F477. 10.1111/j.1468-0297.2010.02387.x

Eichenbaum, M. S. (2019), "Rethinking Fiscal Policy in an Era of Low Interest Rates", Macroeconomic Review, Special Feature B, Monetary Authority of Singapore, Economic Policy Group, April.

Ernst \& Young (2019), Worldwide Corporate Tax Guide 2019, May

European Commission (2014), "Assessing Public Debt Sustainability in EU Member States: A guide", European Economy, Occasional Paper, No 200, Brussels.

European Commission (2017), "Impact of fiscal policy on income distribution", Report on Public Finances in EMU, 71-131.

Fujita, S. and G. Moscarini (2017), "Recall and Unemployment", American Economic Review, 102(7): 3875-3916.

Fujita, S., G. Moscarini and F. Postel-Vinay (2019), "Measuring Employer-to-Employer Reallocation", manuscript, Yale University and University College London.

Girouard, N. and C. André (2005), "Measuring Cyclically-Adjusted Budget Balances for OECD Countries," OECD Economics Department Working Papers, No. 434, OECD Publishing, Paris. https://doi.org/10.1787/787626008442

Hanappi, T. (2018), "Loss carryover provisions: Measuring effects on tax symmetry and automatic 
stabilisation", OECD Taxation Working Papers, No. 35, OECD Publishing, Paris, https://doi.org/10.1787/bfbcd0db-en.

Hijzen, A. and S. Martin (2013), "The role of short-time work schemes during the global financial crisis and early recovery: A cross-country analysis", IZA Journal of Labor Policy, 2:5.

Hijzen, A. and D. Venn (2011), "The Role of Short-Time Work Schemes during the 2008-09 Recession", OECD Social, Employment and Migration Working Papers, No. 115, OECD Publishing.

Hijzen, A. and A. Salvatori (2020), "Designing fair and work-oriented unemployment benefits: The case of Belgium," OECD Social, Employment and Migration Working Papers, No. 237, OECD Publishing, Paris.

IMF (2013), "Staff Guidance Note for public debt sustainability analysis in market-access countries", May, Washington DC.

Immervoll, H. and S. Scarpetta (2012), "Activation and Employment Support Policies in OECD Countries. An Overview of Current Approaches", IZA Journal of Labor Policy, 1:9.

in 't Veld, J., M. Larch and M. Vandeweyer (2012), "Automatic Fiscal Stabilisers: What They Are and What They Do", European Economy Economic Papers, No. 425, April.

Kaplan, G. and G. L. Violante (2014), "A Model of the Consumption Response to Fiscal Stimulus Payments", Econometrica, 82(4), 1199-239.

Keightley, M. P. (2020), "The Tax Treatment and Economics of Net Operating Losses", CRS Report, No. R46377, Congressional Research Service, 29 May.

Kniesner, T.J. and J.P. Ziliak (2002), "Tax Reform and Automatic Stabilization", American Economic Review, 92 (3): 590-612.

Kovalski, M.A. and L. Sheiner (2020), "How does unemployment insurance work? And how is it changing during the coronavirus pandemic?", Brookings Institution, July 20.

Ljungqvist, L. and T.J. Sargent (1995), "The Swedish unemployment experience", European Economic Review, 39:1043-70.

Ljungqvist, L. and T.J. Sargent (1998), "The European unemployment dilemma”, Journal of Political Economy, 106(3):514-550.

Maravalle, A. and $Ł$. Rawdanowicz (2020), "How Effective Are Automatic Fiscal Stabilisers in the OECD Countries", OECD Economics Department Working Papers, No. 1635, OECD Publishing, Paris.

Mohl, P., G. Mourre and K. Stovicek (2019), "Automatic Fiscal Stabilisers in the EU: Size and Effectiveness", European Commission Economic Brief, 45.

OECD (2005), "Labour Market Programmes and Activation Strategies: Evaluating the Impacts", Employment Outlook, OECD Publishing, Paris.

OECD (2006), OECD Employment Outlook 2006: Boosting Jobs and Incomes, OECD Publishing, Paris. https://doi.org/10.1787/empl outlook-2006-en.

OECD (2011a), OECD Economic Surveys: Ireland 2011, OECD Publishing. http://dx.doi.org/10.1787/eco surveys-irl-2011-en

OECD (2011b), OECD Economic Outlook, Volume 2011 Issue 1, OECD Publishing, Paris, https://doi.org/10.1787/eco_outlook-v2011-1-en.

OECD (2012), OECD Economic Surveys: Hungary 2012, OECD Publishing, Paris. https://doi.org/10.1787/9789264127272-en.

OECD (2017), OECD Economic Surveys: Italy 2017, OECD Publishing, Paris. https://doi.org/10.1787/eco surveys-ita-2017-4-en

OECD (2018), Good Jobs for All in a Changing World of Work: The OECD Jobs Strategy, OECD Publishing, Paris. https://doi.org/10.1787/9789264308817-en 
OECD (2019), Tax Policy Reforms 2019: OECD and Selected Partner Economies, OECD Publishing, Paris. https://doi.org/10.1787/da56c295-en

OECD (2020a), OECD Economic Outlook, Volume 2020 Issue 1, OECD Publishing, Paris, https://doi.org/10.1787/0d1d1e2e-en.

OECD (2020b), "Job retention schemes during the COVID-19 lockdown and beyond", OECD Policy Responses to Coronavirus (COVID-19), OECD Publishing, Paris. https://read.oecdilibrary.org/view/?ref=135 135415-6bardplc5q\&title=Job-retention-schemes-during-the-COVID-19lockdown-and-beyond

Parker, J. A., N. S. Souleles, D. S. Johnson and R. McClelland (2013), "Consumer Spending and the Economic Stimulus Payments of 2008", American Economic Review, 103(6), 2530-53.

Price, R., T. Dang and J. Botev (2015), "Adjusting fiscal balances for the business cycle: New tax and expenditure elasticity estimates for OECD countries", OECD Economics Department Working Papers, No. 1275, OECD Publishing, Paris. https://doi.org/10.1787/5jrp1g3282d7-en

Sahm, C. (2019), "Direct Stimulus Payments to Individuals", in Boushey, H., R. Nunn and J. Shambaugh (eds), Recession Ready: Fiscal Policies to Stabilize The American Economy, report, the Hamilton Project, Washington Center for Equitable Growth.

Sahm, C. R., M. D. Shapiro and J. Slemrod (2012), "Check in the Mail Or More in the Paycheck: Does the Effectiveness of Fiscal Stimulus Depend on how it is Delivered?" American Economic Journal: Economic Policy, 4(3), 216-50.

Sutherland, D., P. Hoeller, B. Egert and O. Rohn (2010), "Counter-Cyclical Economic Policy", OECD Economics Department Working Papers, No. 760, OECD Publishing, Paris.

Stone, C. and W. Chen (2014), "Introduction to Unemployment Insurance", Center on Budget and Policy Priorities.

van den Noord, P. (2000), "The Size and Role of Automatic Fiscal Stabilisers in the 1990s and Beyond", OECD Economics Department Working Papers, No. 230, OECD Publishing, Paris. https://doi.org/10.1787/816628410134 


\section{Annex A. Evolution of automatic stabilisers by household type}

1. Disaggregate data at the level of household types provide additional information on the factors behind an observed change in the stabilisation properties of the tax system in the country as a whole (Figure A.A.1). For example, Canada recorded only a slight strengthening of tax-based automatic stabilisers at the aggregated level. However, this result hides very different and opposite tendencies across household types as tax-based automatic stabilisers strongly strengthened only for one-earner married couple with children but weakened for childless households.

Figure A Error! No text of specified style in document..1. Level and changes in the strength of taxbased automatic stabilisers across household type

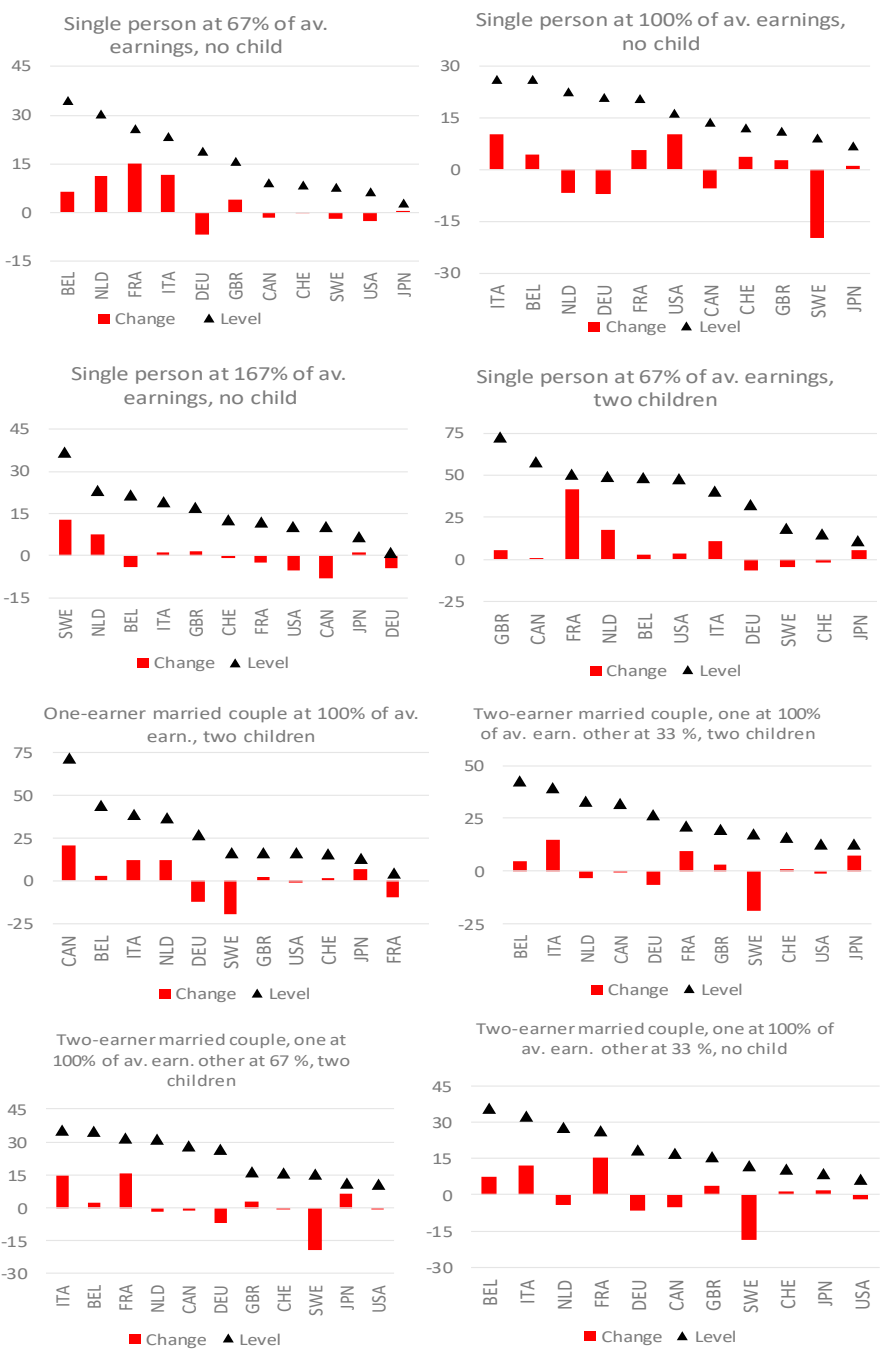

Note: The level refers to the 2018 (or most recent) annual value of the indicator of the strength of tax-based automatic stabilisers; the indicator takes value between 0 and 100 , with a value of 0 pointing to no stabilisation and a value of 100 to full stabilisation. The change reports the difference between 2018 and 2000, with a positive change pointing to an increase in the strength of tax-based automatic stabilisers.

Source: OECD Taxing Wages 2019 database; and authors' calculations. 